NBER WORKING PAPER SERIES

AGING AND LABOR FORCE PARTICIPATION:

A REVIEW OF TRENDS AND EXPIANATIONS

\author{
Robin L. Lumsdalne \\ David A. Wise
}

Working Paper No. 3420

NATIONAL BUREAU OF ECONOMIC RESEARCH 1050 Massachusetts Avenue

Cambridge, MA 02138

August 1990

This paper is part of NBER's research program in Aging. Any opinions expressed are those of the authors and not those of the National Bureau of Economic Research. 
NBER Working Paper No. 3420

August 1990

AGING AND LABOR FORCE PARTICIPATION:

A REVIEW OF TRENDS AND EXPLANATIONS

\begin{abstract}
The American population is aging rapidly. Persons 65 and over who now constitute about one-fifth of the population will constitute about two-fifths of the population by 2040 . In addition, Individuals are living longer. Yet the labor force participation of older Americans has fallen dramatically in recent years. This paper discusses this trend and the principal arguments put forth to explain it. The paper is in two parts. The first part reviews trends in labor force participation and associated trends in Soclal Security (SS) coverage, firm pension plan coverage, and other factors that are 1ikely to be associated with the labor force participation trends, including demographics. The second part of the paper discusses the incentive effects of SS and retirement plans, with emphasis on firm pension plans.
\end{abstract}

Robin L. Lumsdaine Department of Economics Littauer Center Harvard University Cambridge, MA 02138
David A. Wise

Kennedy School of Government

Harvard University

79 Kennedy Street

Cambridge, MA 02138 
AGING AND LABOR FORCE PARTICIPATION: A REVIEW OF TRENDS AND EXPLANATIONS

by

Robin L. Lumsdaine and David A. Wise*

The American population is aging rapidly. Persons 65 and over who now constitute about one-fifth of the population w11l constitute about two-fifths of the population by 2040. In addition, Individuals are living longer. Yet the labor force participation of older Americans has fallen dramatically in recent years. This paper discusses this trend and the principal explanations put forth to explain 1t. The paper is in two parts. The firat part roview trends in labor force particlpation and associated trends in social security (SS) coverage, f1rm pension plan coverage, and other factore that are $11 \mathrm{kely}$ to be assoclated with the labor force particlpation trends. The second part of the paper discusses the incentive effects of ss and retirement plans, with emphasis on firm pension plans. The intent is to summarize the facts and the research that has attempted to explain them. The presentation 1s primerily graphical. We begin with a simple conceptual framework.

\section{Conceptual Eromework.}

To help to organize the discussion that follows and to put the Ideas in context, a conceptual framework of the retirement decision 1s outlined in

\footnotetext{
* We have paraphrased and borrowed freely from papers by Kotlikoff and W1se (1985, 1987, 1989) and Stock and wise [1988, 1989]. Data gathered by several other authors have also been used, often in a format different from the original author's presentation. In all cases the original sources are c1ted.

Financial support was provided by the National Institute on Aging, grant numbers P01 AG05842 and T32 AG00186, and by the Hoover Institution.
} 
figure 1, which summarizes several stylized facts. ${ }^{1}$ Several factors have Important influences on the retirement declsion as workers age. As health and functional ablity deterforate, the disut1lity of work 1ncreases and the relative desire for lolsure increases, Indicated by the line labelled $L$ in the flgure. Real wage earnings typlcally rise over some portion of the working I1fe, but leter decline with age, as Indicated by $W$. Lower wage earnings and greater hardship assoclated with working tend to incroase the incentive to rotire. As employees age they may also accumulate more personal saving and tholr entitloment to SS and firm pension bonefits increases. Thus if the

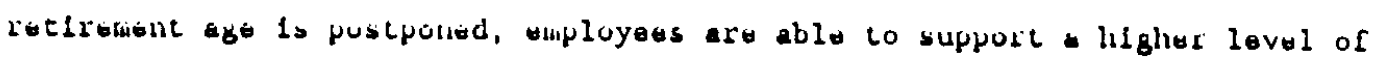
consumption after retirement. In addition, any given lovel of personal saving or SS and penation entitloment can support a higher annual consumption lovel if rotiroment 1s postponed; there are fower romalning years of 11 fe over which support must be provided. This is summerized as B in the flgure. The larger these benefits, the greater the incentive to retire.

The central theme of the discussion below is the upward shift over time In the relationship between benefits and age; given age, ss and pension entitlements have increased. Thus the incentive to retire has increased. With respect to most of the discussion below, it may be assumed that the relationship between real wage earnings and age, and the relationship between the disutility of work (desire for lelsure) and age, have not changed over time.

Worker productivity also declines with age. It is often argued that productivity is greater than the wage early in the working 11 fe and less than

\footnotetext{
IPatterned after Fig. 10.1 in Nalebuff and Zeckhauser [1985].
} 
(3)

Figure 1: Summary of Factors that Influence Retirement

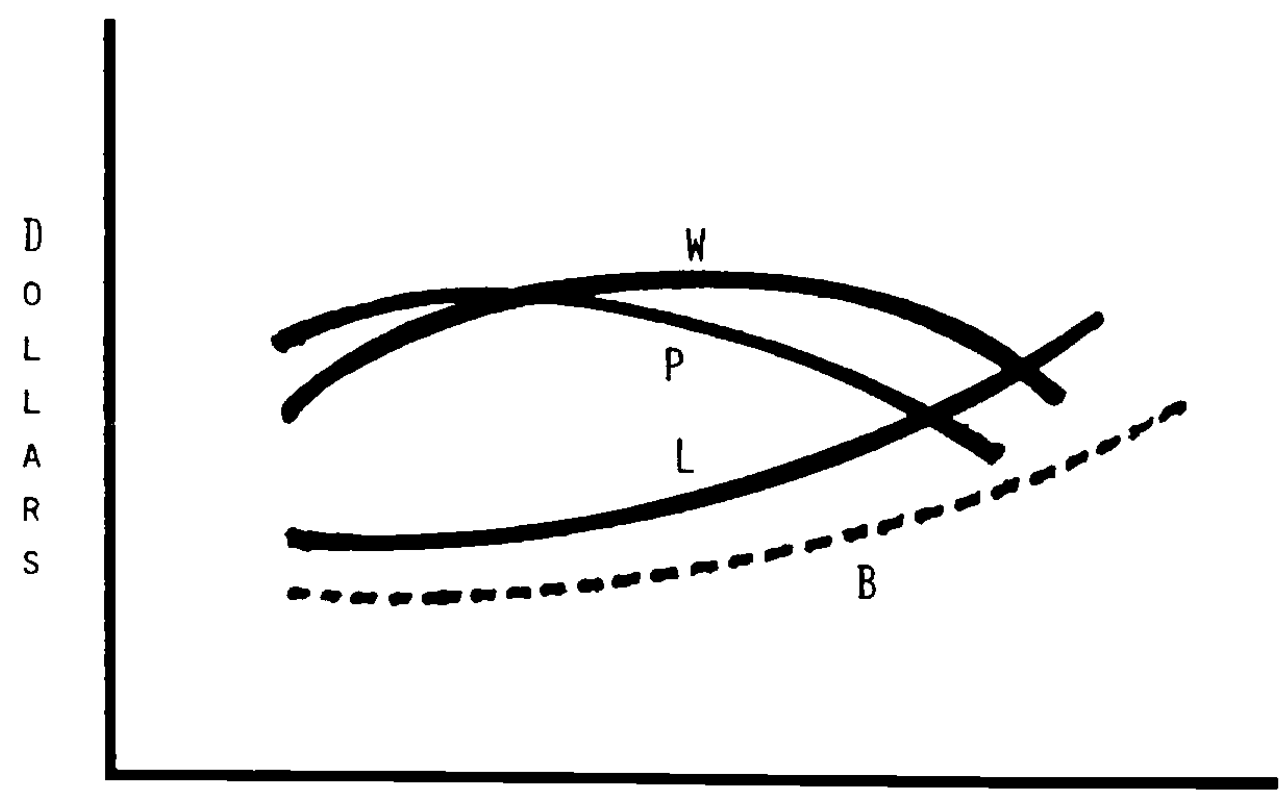

AgE 
the wage later in the working iffe. This is the assumption reflected in the relationship between worker productivity, $P$, and the wage shown in the figure This relationship is often put forth as an explanation for the structure of private pension plans, that typically encourage early retirement, as discussed below.

\section{Life Expectancy, Labor Force Participation. and Associated Trends,}

A. Lfe Expectancy and the Age Composition of the U,S. Population.

Americans are living longer and the proportion of the population that is old is increasing rapidy. In 1950, for example, the annual death rate of white men 75 to 79 was 90.1 per 1,000 ; by 1980 it had fallen to $80.7, a 10$ percent reduction. Assuming current trends, the profected death rate for the year 2000 is 63.9 , a further 21 percent reduction. The reductions for white women are even larger, as shown in figure $2^{2}$

An implication of the lower death rates is a marked increase in 11 fe expectancy, especially for women. Men who were 65 in 1950 could expect to live 12.8 more years; In 1980 they could expect to live 14.2 more years, an 11 percent increase. (See figure 3a.) over the same thirty-year period, the IIfe expectancy of women who were 65 increased by over 23 percent, from 15 to 18.5. (See figure 3b.)

The overall aging of the population probably has more important policy implications than increasing individual life expectancy. The proportion of

2These data were taken from Poterba and Summers [1987], who obtained their data from the U.S. Department of Health and Human Services, National Center for Health Statistics, Vital Statistics of the United States, Volume 2: Mortal1ty. 
(5)

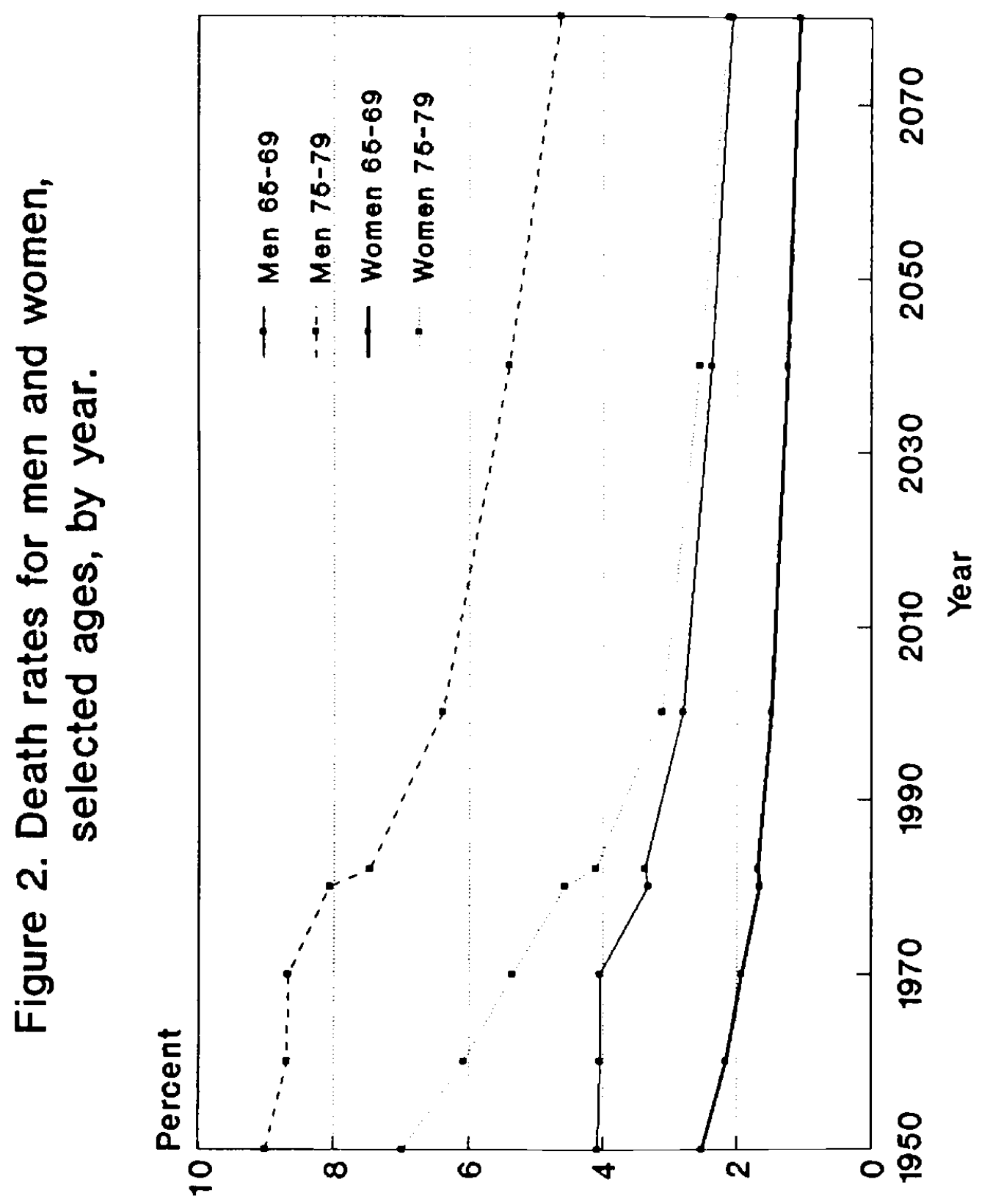


(6)

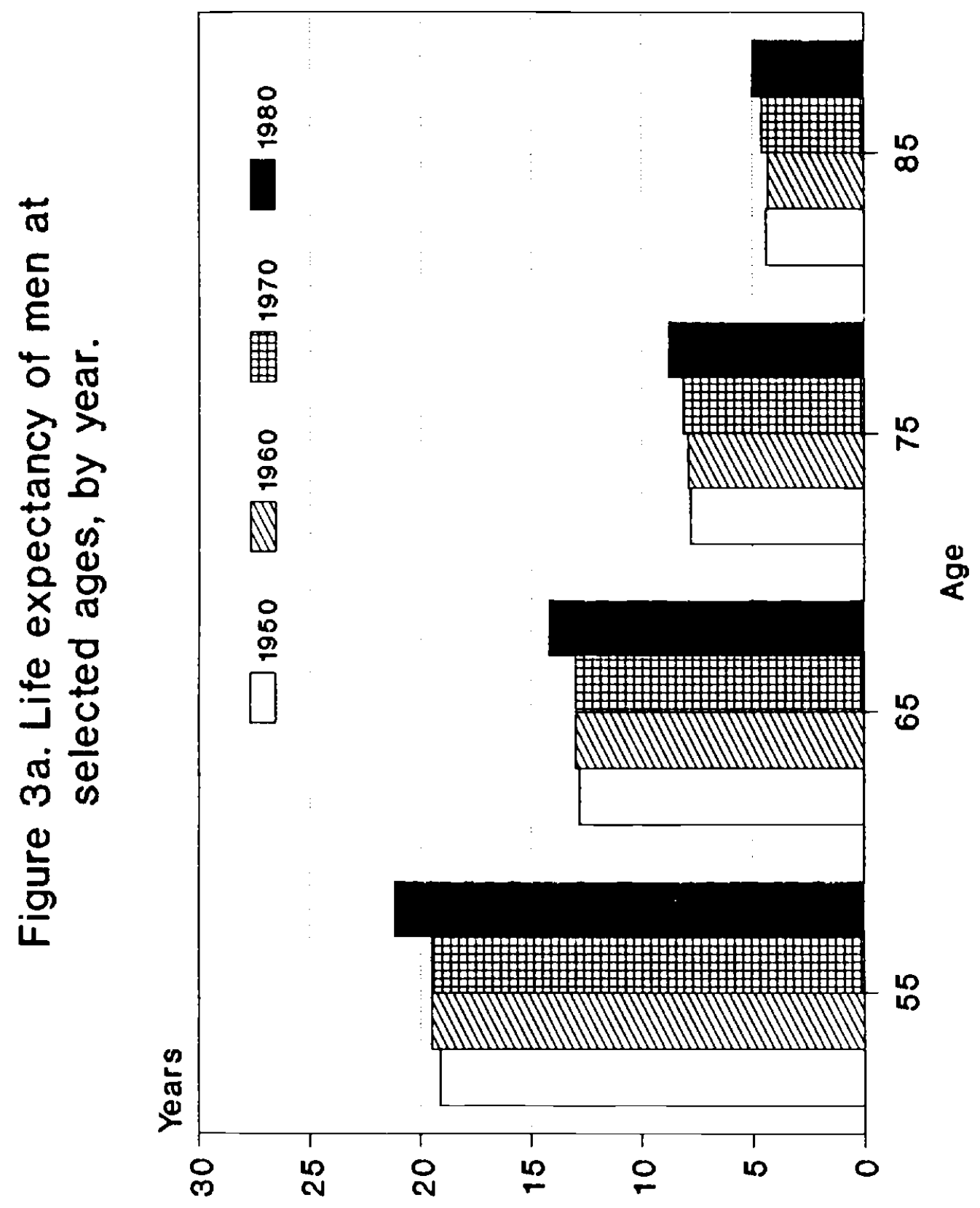




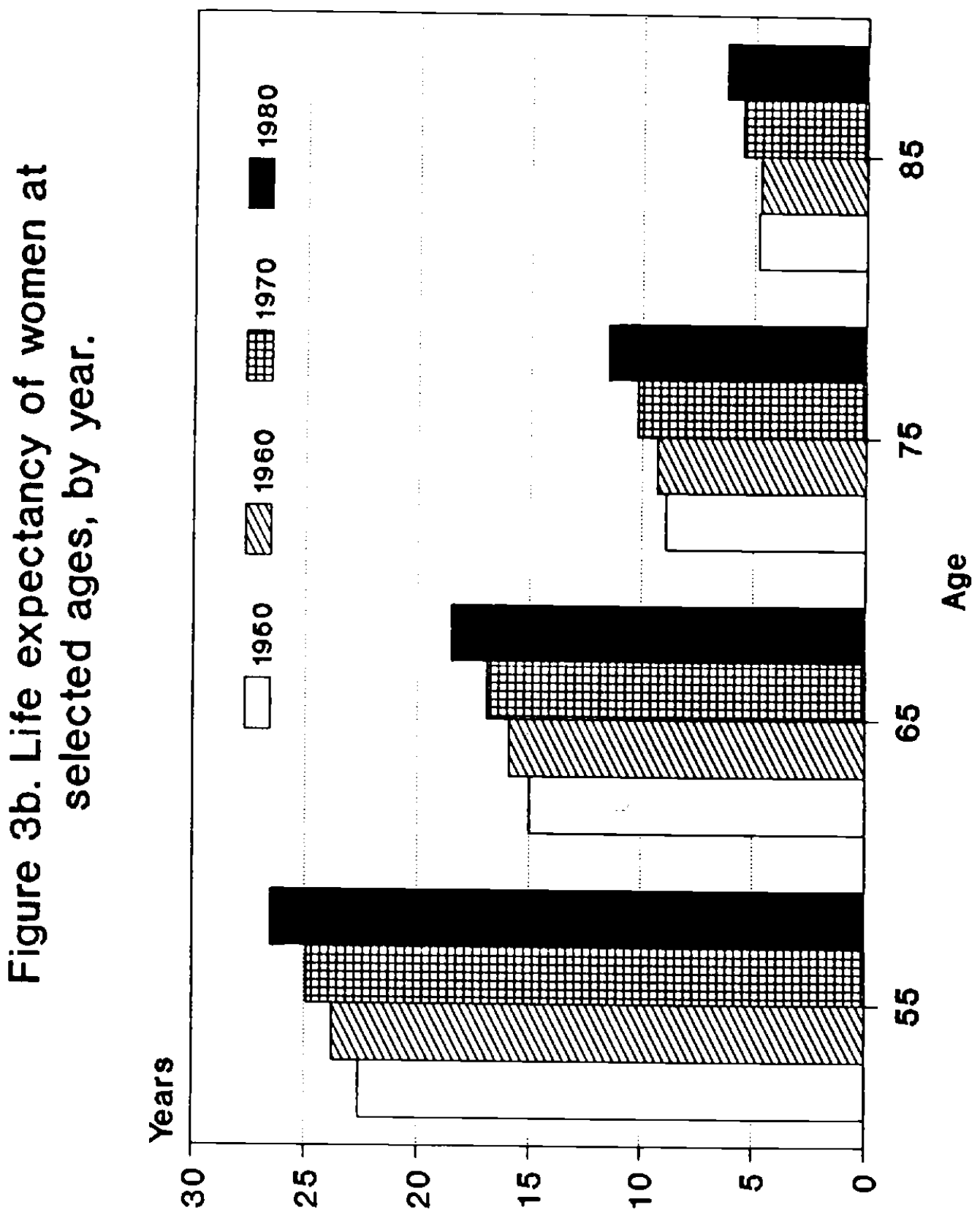


the population 55 and over has increased from about 15 percent in 1940 to about 21 percent in 1980. By 2020, almost 31 percent of the population will be in this age group. (See figure 4a.) The elderly (those over 54), who now constitute about one-fifth of all adults, will constitute about two-fifths of all adults by 2040 .

The oldest age groups are growing the fastest. Only 0.3 percent of the population was over 85 in 1940; the proportion had increased to 1.0 percent by 1980, mostly since 1960. (See figure 4b.) The projected proportion is 2.4 in 2020. The proportion between 65 and 74 increased from about 5 percent of the population in 1940 to close to 7 percent in 1980; the 2020 projection is 10 percent. Thus an increasingly large fraction of the population is older than typical retirement ages. As emphasized below, the dramatic reduction in retirement ages magnifies this effect.

From the point of view of the individual, increasing life expectancy induces later retirement. If other factors remain the same, longer life expectancy means that any given level of pension and SS entitlement, or of personal saving, must be used to support consumption over more retirement years. From the point of view of society, a larger older population means that a smaller labor force must support a larger number of retirees.

\section{B. Labor Force Participation.}

Although a larger and larger fraction of the population is old and Individual life expectancy is increasing, workers are leaving the labor force at younger and younger ages. Thus there are more older people, living longer, working less.

A recent study of Ransom and Sutch [1988] shows that the labor force participation rates of men over 60 were essentially constant between 1870 and 


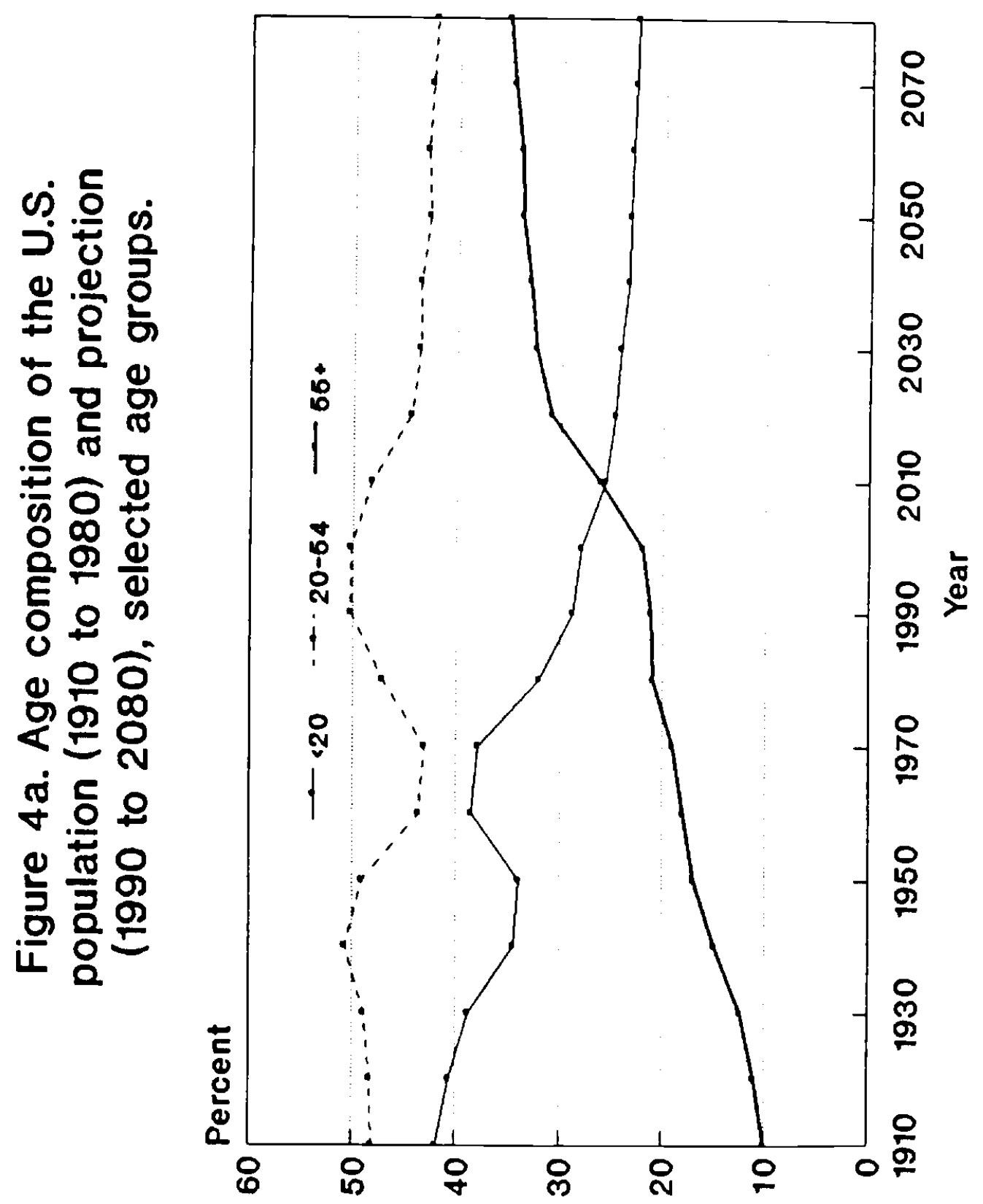




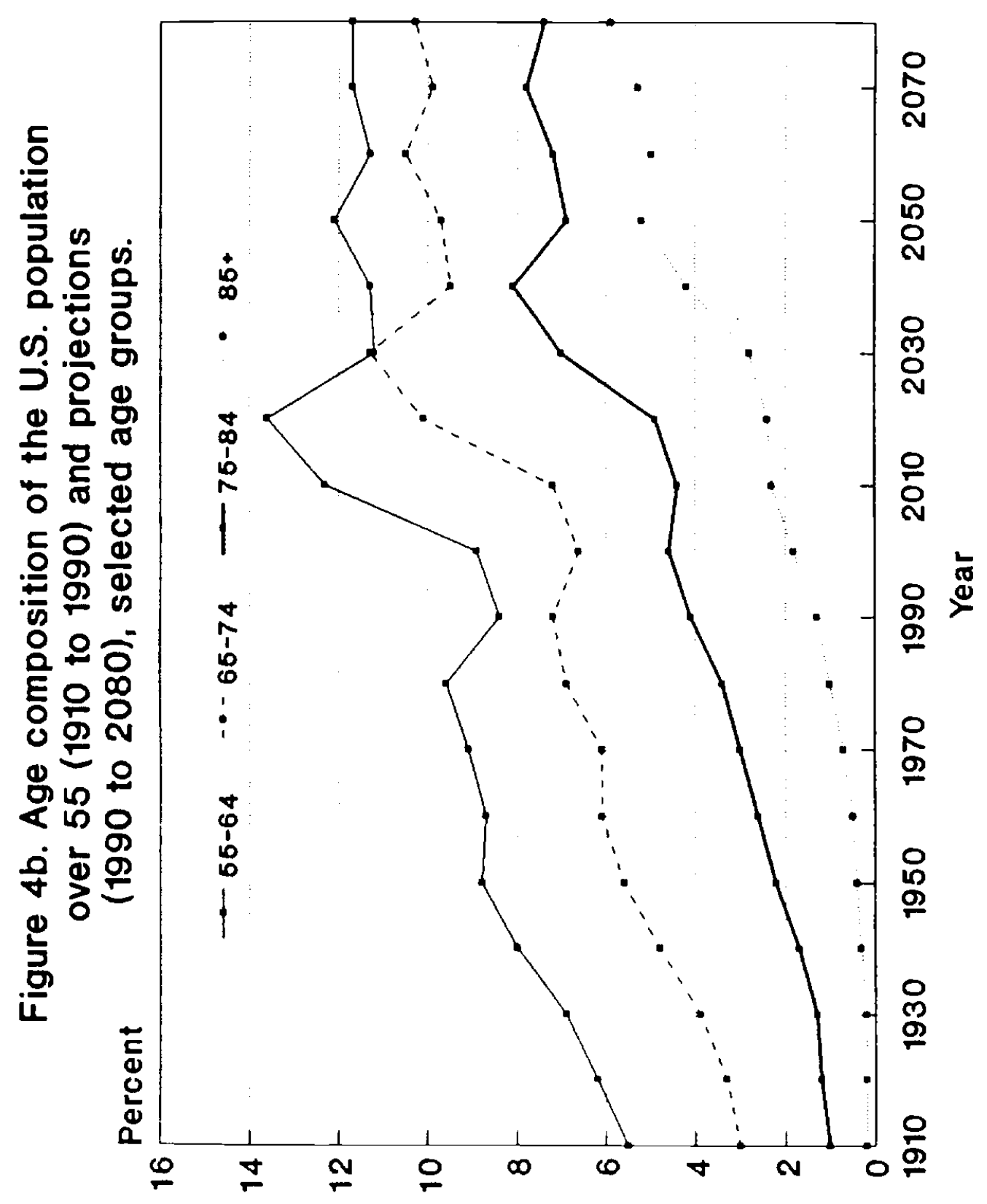


1930. Indeed for most older age groups, the rates in 1937 were essentially the same as in 1930, according to their study. Since that time the labor force participation rates of older men have fallen continuously. Adjusted for the shift away from agricultural employment, the rate increased from a little over 50 percent in 1870 to almost 65 percent in 1930 and then fell to about 30 percent by 1980. Social Security was introduced under the Social Security Act of 1935. Company pensions were spurred by the Revenue Act of 1942, that granted tax incentives to firms to establish pension plans. The Ransom and Sutch data, based on the decennial censuses, are reproduced in figure $5 a$. These data, as reported in Sandefur and Tuma (1987), also have been used to construct labor force participation rates by age group for men and women at 10 year intervals, beginning in 1940. (See figures $5 b$ through $5 d.)^{3}$ The rates for men fell in each age group. For example, 61.4 percent of men 55 and over were in the labor force in 1940, by 1970 the proportion had fallen to

${ }^{3}$ Sandefur and Tuma [1987]. Labor force participation by gender and age group can be computed from Sandefur and Tuma's tables 1, 2, 3, and 10 . For example, the labor force participation of men in a given age category is equal to the percentage of men in that age group that are employed divided by the percentage of men in that age group (which is given in table 3, panel a). Since the tables are divided by gender and race simultaneously, the percentage of employed men in a given age group is the percentage of white employed men in that age group plus the percentage of nonwhite employed men in that age group. For each race, the percentage of employed men in an age group is the product of the following: the percentage of men of a given race and age that is employed, the percentage of the population of a given race and age that is male, the percentage of a given age that is a specific race. These are obtained from tables 10,3 , and 2 respectively. To aggregate age groups, additional information regarding the percentage of the population that is a given age group is required; these data are found in table 1. 


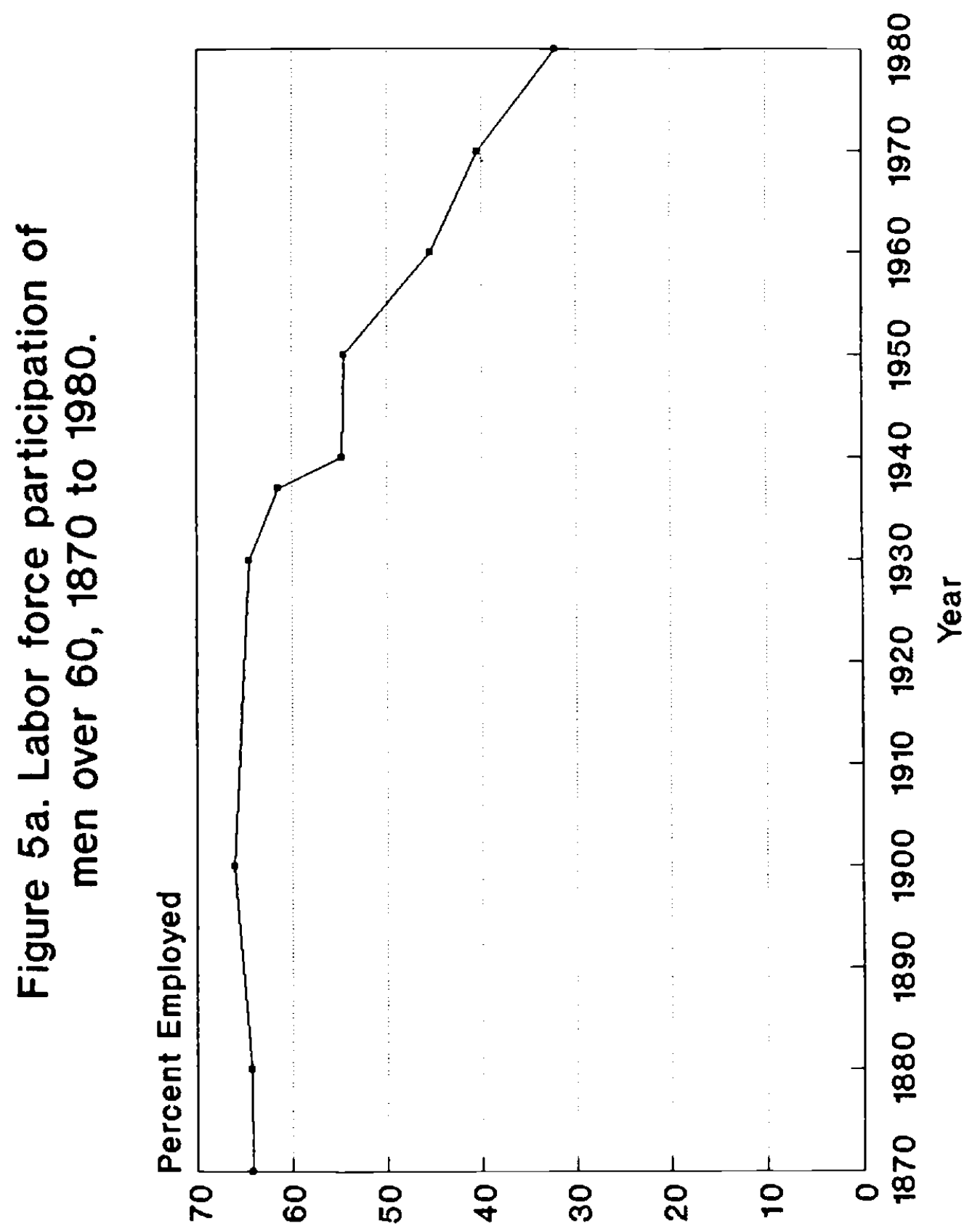




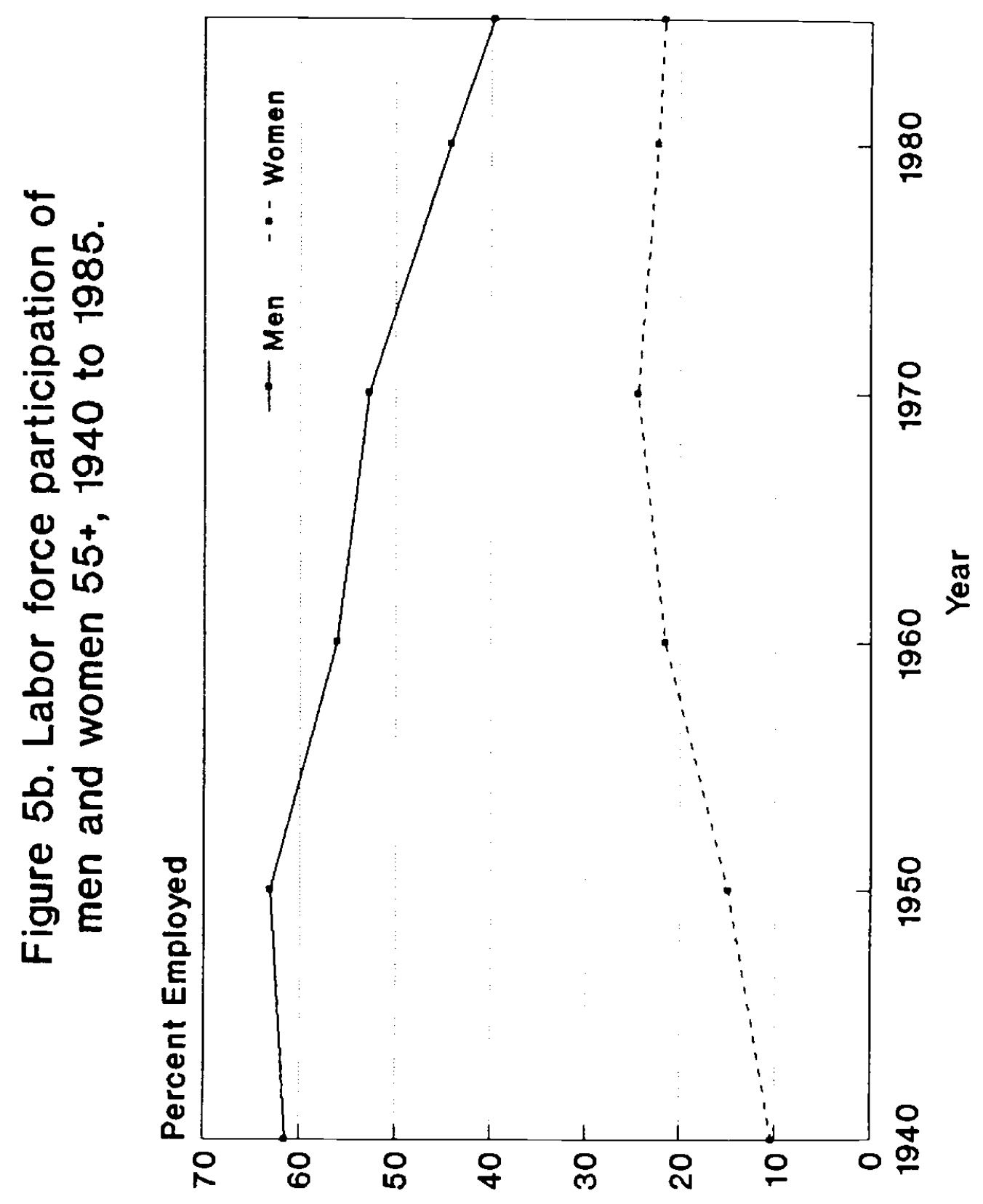


(14)

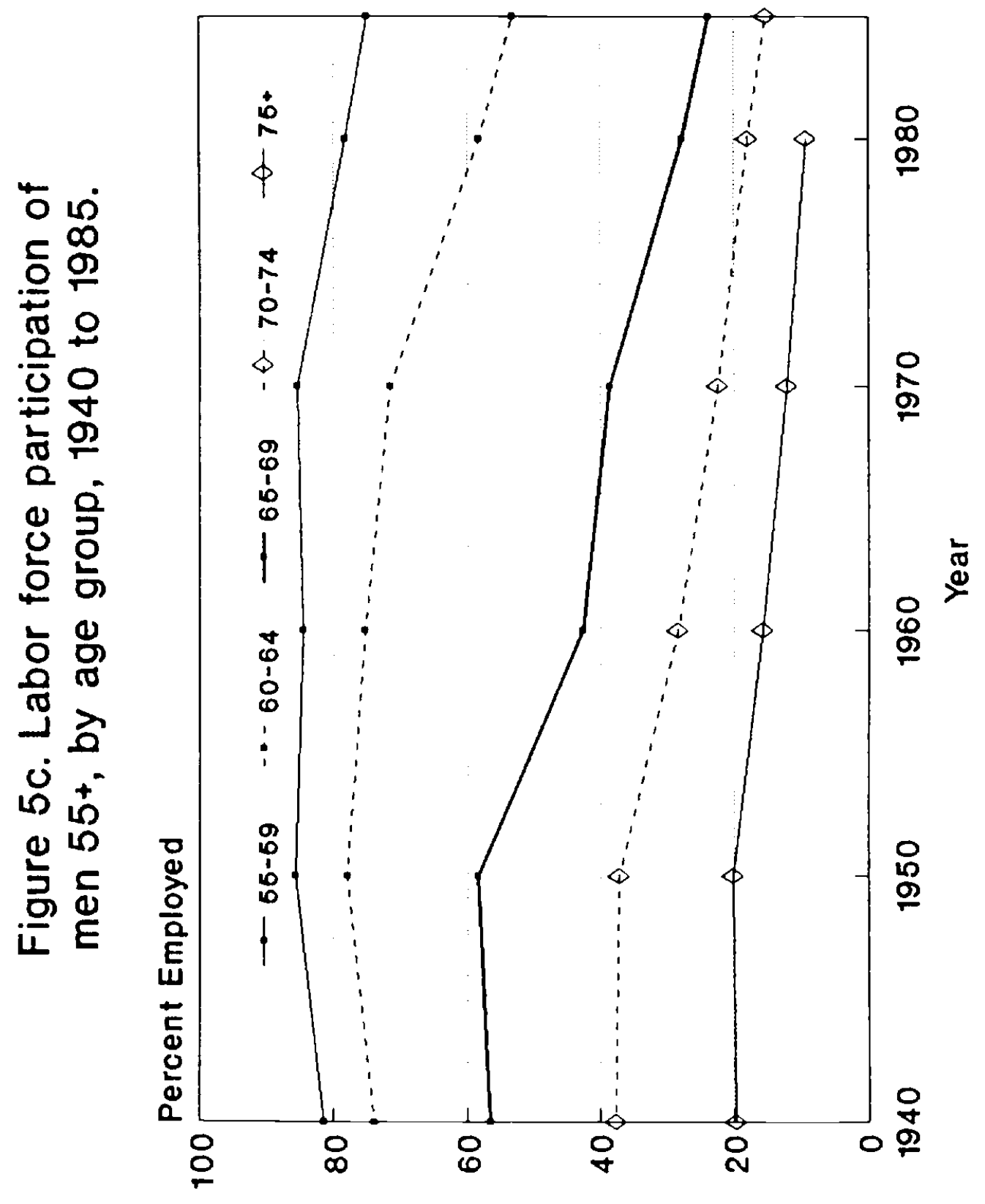




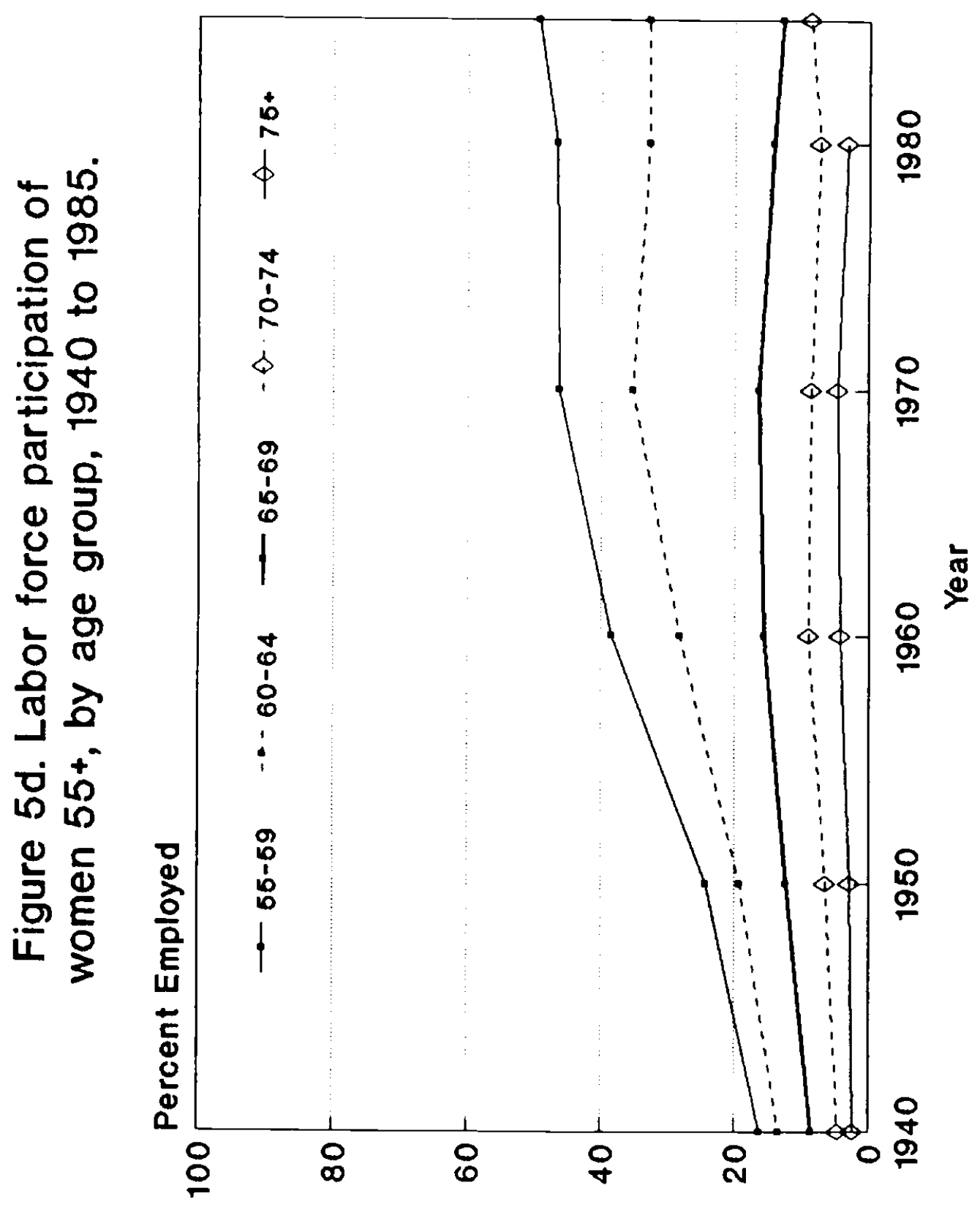


52.7 , by 1985 only 39.6 percent of men In this age group were in the labor force. The participation rates of women 55 and over increased unt 111970. But ince 1970, even the rates for women have fallen. (See figure 5b.) Indeed for both men and women there was an abrupt change in labor force participation rates in the early 1970's: for men the reduction was accelerated in most age groups and for women the rates that had been Increasing began to decline.

\section{Associated Trends.}

What has enabled people to leave the labor force at younger and younger ages and st1ll maintain consumption after retirement? It seems evident that this has been made possible by Social Security benefits and by firm pension plans. Before discussing trends in SS and pension coverage, it is useful to establish first that support in old age is typically not financed by personal saving.

1. The Composition of Total Wealth.

Based on the recent Survey of Income and Program Participation (SIPP), Vent 1 and Wise [1989] have computed the composition of total wealth for all households, for homeowners, and for renters in 1984. The results are summarized in figures $6 a, 6 b$, and $6 c$. The amounts reflect median wealth by asset category. It is clear from figure 6a that most families approach retirement age with very little personal saving other than housing equity. For example, among households with heads 60 to 65 , the median of liquid wealth is only $\$ 6.6$ thousand; the median of housing equity is $\$ 43.0$ thousand. ${ }^{4}$

${ }^{4}$ Liquid wealth is broadly defined to include interest earning assets held in banks and other institutions, mortgages held, money owed from sale of businesses, U.S. Savings Bonds, and checking accounts, equity in stocks and mutual fund shares, less unsecured debt. 


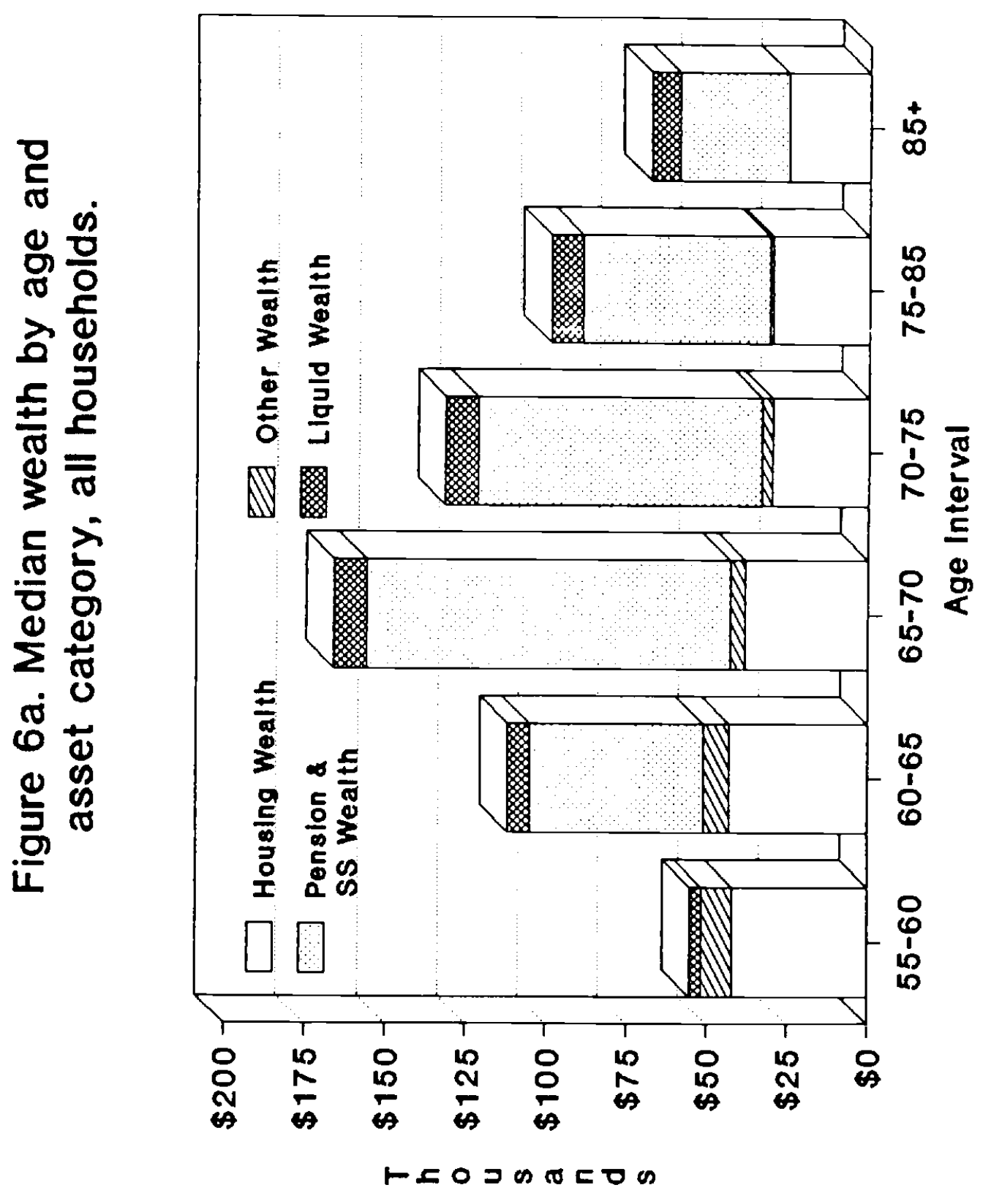




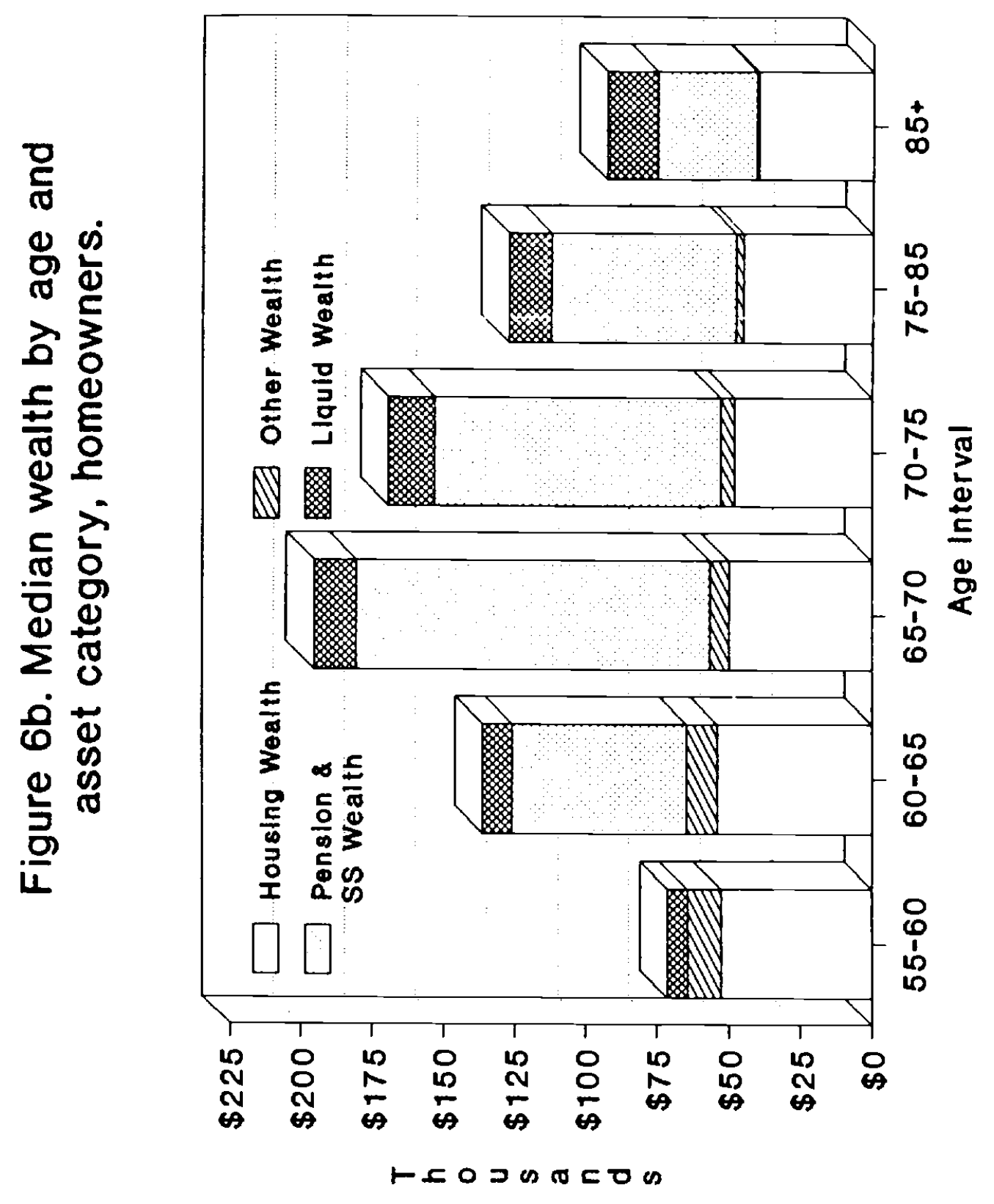




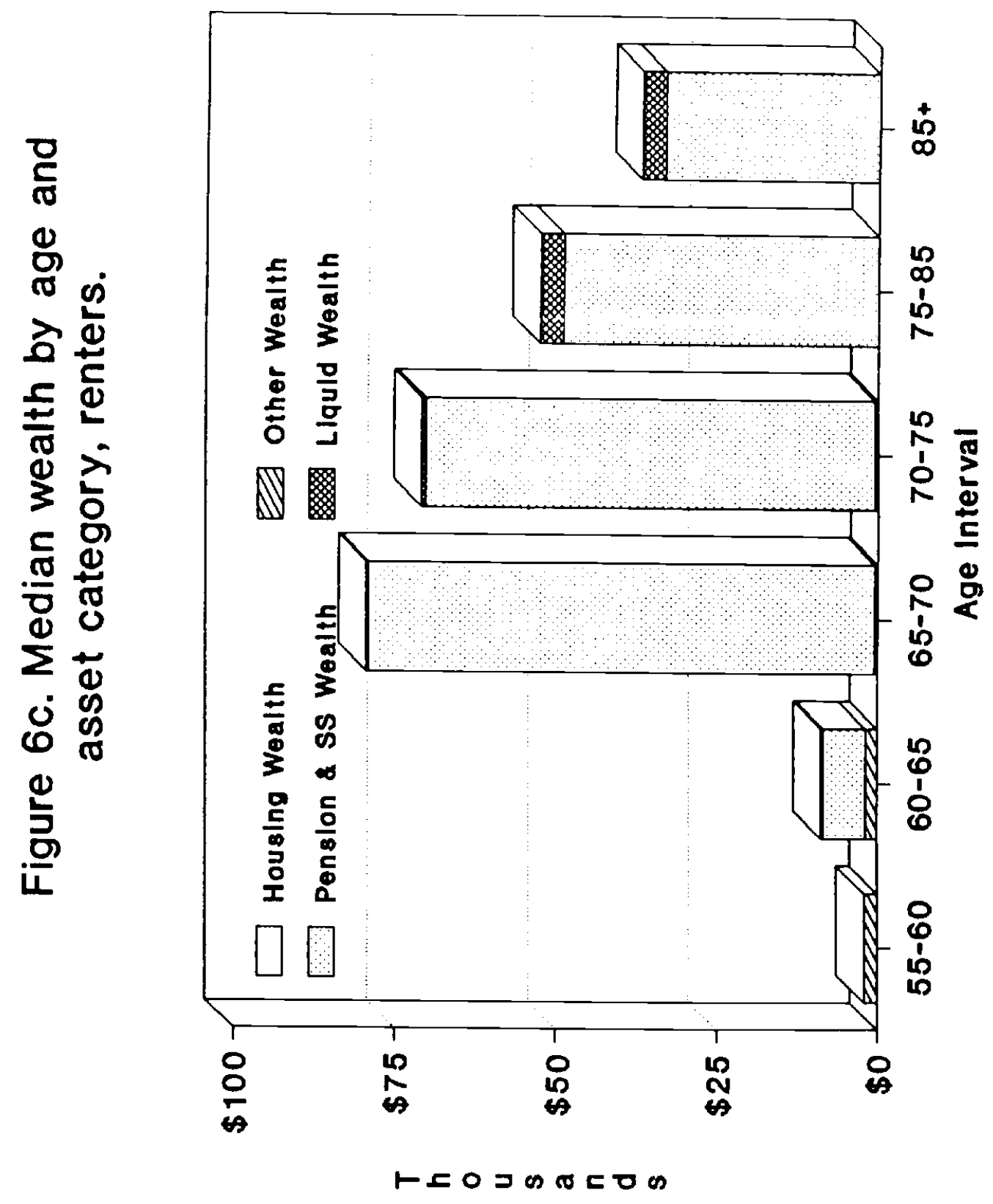


The majority of families rely heavily on Social Security (SS) benefits for support after retirement, and to a more limited extent on the saving that is done for them by employers, through defined benefit pension plans. The Survey of Income and Program Participation (SIPP) data, from which these figures were computed, allow estimation of the value of SS and pension plan benefits only after the payments are received. ${ }^{5}$ Thus wealth in the form of SS and pensions is only recorded for persons who have begun to receive the payments. Most persons have retired by 65 and thereafter are receiving the benefits to which they are entitled. About 59 percent of households with reference persons between 65 and 70 receive pension benefits; 89 percent receive SS benefits. The present value of pension and SS wealth is based on life tables together with the amount of the annual payments. Social Security benefits are indexed to inflation; private pension benefits typically are not. ${ }^{6}$ As can be seen from figure $6 a$, SS and pension wealth is by far the most important component of the wealth of most elderly. Among households with heads 65 to 70, for example, the median of SS and pension wealth combined is $\$ 113.4$ thousand; the median of housing wealth is $\$ 38.0$ thousand and the median of liquid financial assets is only $\$ 10.0$ thousand. The decline in SS and

${ }^{5}$ The SIPP data do not contain SS earnings histories (that determine SS benefits), nor do they contain detailed pension plan provisions.

${ }^{6}$ The present values of pension and SS benefits are the discounted survival weighted streams of income from each source received by the reference person and the spouse if present. Discounting is at 6 percent and survival probabilities are calculated from mortality tables by sex. Payments from SS, military pensions, federal employee pensions, and the railroad retirement pension are assumed to be indexed at an annual rate of 4 percent. All other sources of pension income are not indexed in the wealth calculations. 
pension wealth with age is largely an artifact of declining life expectancy. The lower housing equity of older households is a cohort effect and does not reflect a reduction of housing equity as individual households age; in fact. housing equity increases on average as the elderly age; there is little change in housing equity even among families that move from one home to another. Comparison of figures $6 \mathrm{~b}$ and $6 \mathrm{c}$ shows that households who rent have substantially less wealth than homeowners in all asset categories. The median total wealth of homeowners is $\$ 170.4$ thousand; the median for renters is $\$ 59.3$ thousand. Renters, who comprise about 20 percent of all households, have virtually no liquid assets.

In sumary: the majority of elderly households live on Social Security and pension benefits.

\section{Social Security Coverage.}

It is clear from figure $5 a$ that the trend to earlier retirement began between the passage of the Social Security Act in 1935 and the Revenue Act of 1942. The 1942 Revenue Act granted tax incentives to firms to establish pension plans. Indeed, after adjusting for the reduction in agricultural employment, there was a sharp reversal in the prior trend to later retirement, as shown by Ransom and Sutch [1988).

The percent of persons 65 and over receiving ss benefits increased from about 20 percent in 1940 to 85 percent in 1960; now about 95 percent receive SS benefits. (See figure 7.) In addition, the level of benefits has increased sharply. The benefits for a retired male worker increased from about 14 percent of median male income in 1950 to 37.5 percent in $1980 .^{7}$ Thus

\footnotetext{
${ }^{7}$ See Tuma and Sandefur [1988].
} 


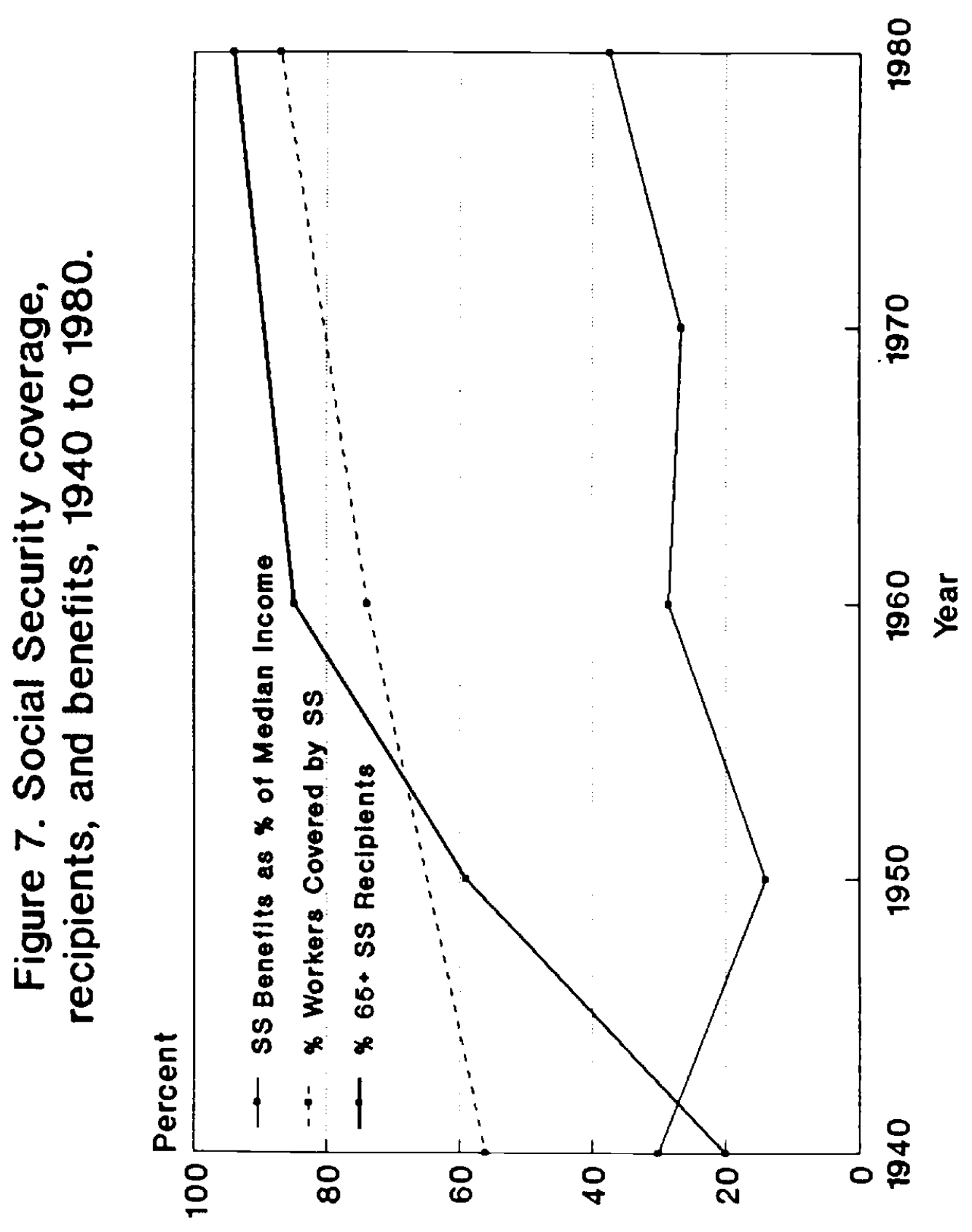


not only has coverage been extended to virtually the entire labor force, but the standard of living that the beneflts can support has also increased sharply.

3. Etrm Pension Plans.

The proportion of the workforce covered by a firm (or a federal or state or local government) pension plan Increased from 23.8 to 48.6 percent between 1950 and 1979. Now about 50 percent of the workforce is covered by a pension plan. Most of the growth in pension coverage occurred in the 1950s. The proportion of the older population ( 55 and over) collecting pension benefits continues to Increase, as shown In flgure 8. By 1984, 30.8 percent of persons 55 and over, and 39.0 percent of persons 65 and over were collecting pension benefits from some source, according to the SIPP.

In short: It is evident that the expansion of SS and firm pension plans has allowed and encouraged earlier retirement. In addition to the Incowe Incentive created by the entitlement to retirement income, the discussion below shows that the timing of the accrual of pension entitlements, created by firm pension plan provisions in particular, provides a strong incentive to retire early. These provisions create large increases and decreases in the total compensation from working at particular ages. Thus the retirement beneflt Inducement to retire results from both income and price (wage) effects.

\section{Earnings of O1der Employees.}

Like the earnings of younger employees, the earnings of older workers Increased consistently from 1940 to 1970 . But after 1970, the earnings of the oldest employees began to decline, and the earnings of all older workers were declining by 1980. (See flgure 9.) For example, the average 1985 annual 


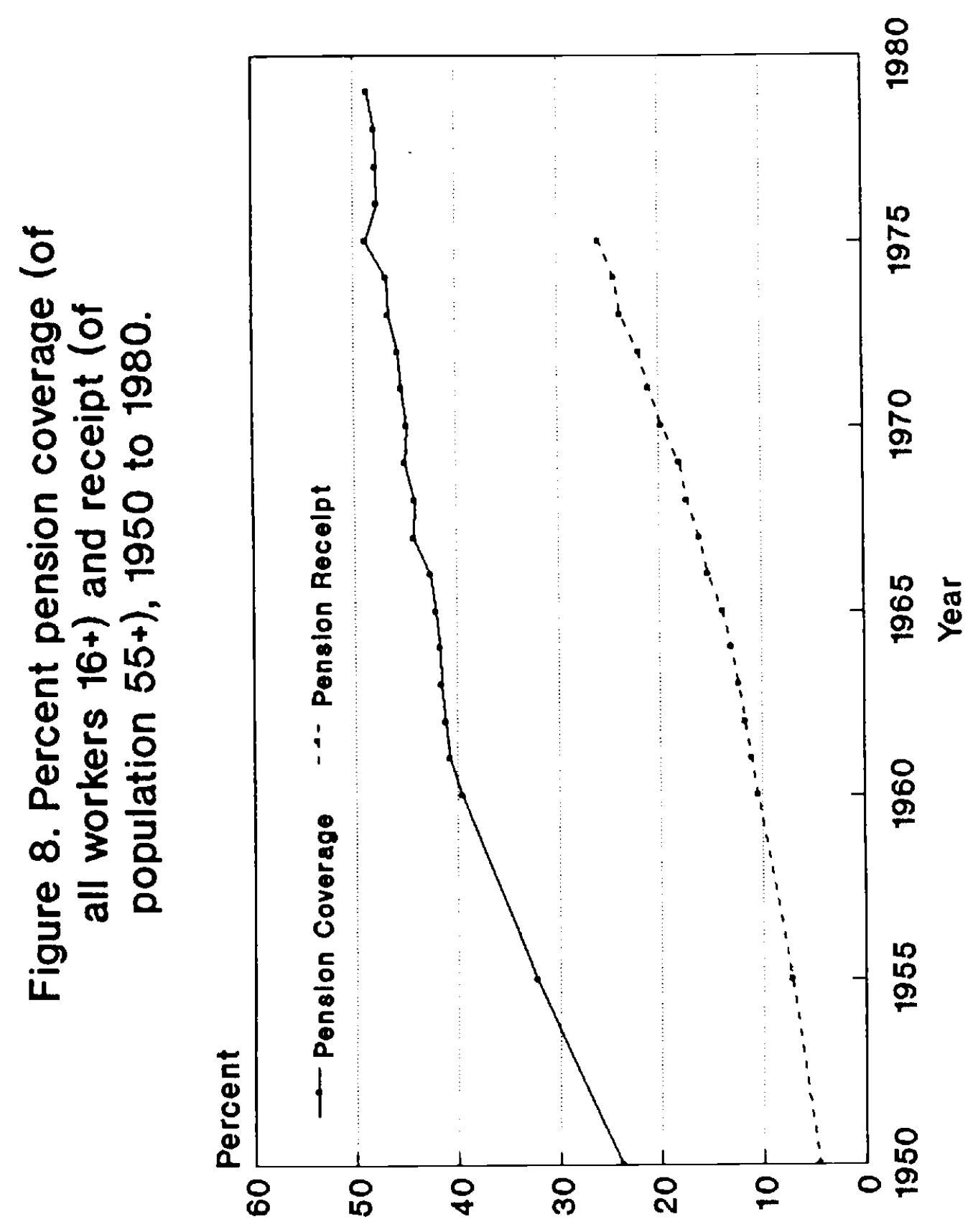




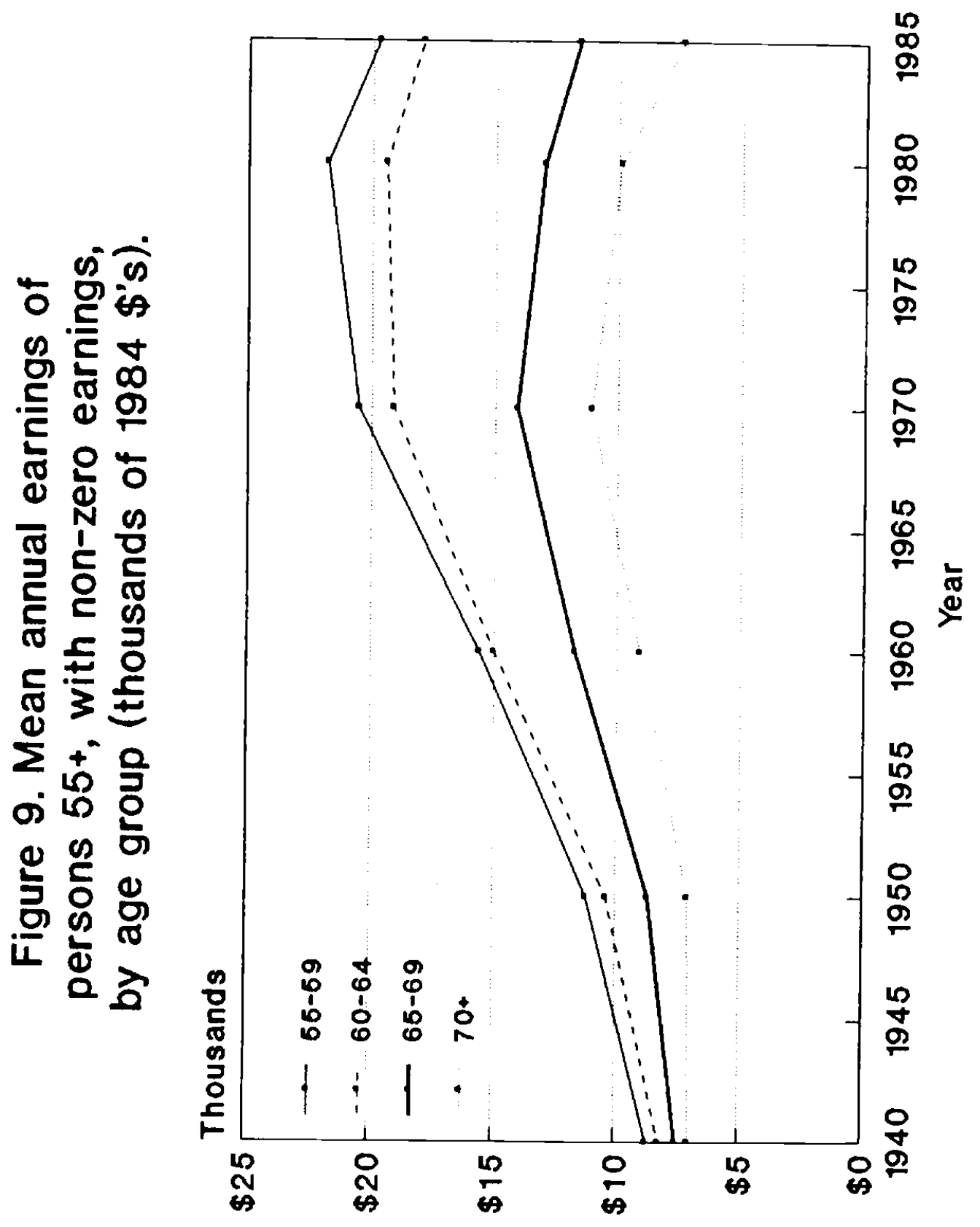


earnings of employees 65 to 69 were about the same in real terms as they were 25 years earlier, in 1960. The 1985 earnings of employees 55 to 59 were lower than they were in 1970. These data may be affected by selective retirement of the highest paid employees and by part-time work, but there is ample evidence of a general decline in real wages across all age groups in the United States since about 1972. Thus falling real wage earnings may also have contributed to earlier retirement in recent years.

\section{The Income of the Elderly.}

Although the labor force participation rates of older Americans have fallen dramaticaliy in recent years, the average income of the elderly has Increased sharply. Income data have been tabulated by Hurd and Shoven [1982] for several years between 1963 and $1978 .^{8}$ (See figures 10a and 10b.) Between 1960 and 1980, the labor force participation rates of men 65 and older fell by 37.5 percent, from 31.7 to 19.8. Yet the incomes of the elderly increased more than three fold over approximately the same time perlod. The proportion of Income from earnings declined, while the proportion from SS, firm pension benefits, and government medical plans increased substantially. The Hurd and Shoven computations include an estimate for the user cost of housing and an estimate for the Income equivalent of Medicare and Medicald Insurance (valued at $\cos ($ ). According to their numbers, the proportion of the income of the elderly derived from their own earnings declined from 29 to 18 percent between 1963 and 1978. Over the same perlod the proportion from SS, firm pension plans, and government medical insurance increased from 32 to 51 percent. The

${ }^{8}$ The Hurd and Shoven data are based on several U.S. Bureau of the Census and U.S. Department of Health, Education, and Welfare, Soclal Security Administration reports, and the 1978 Survey of the Elderly. 
(27)

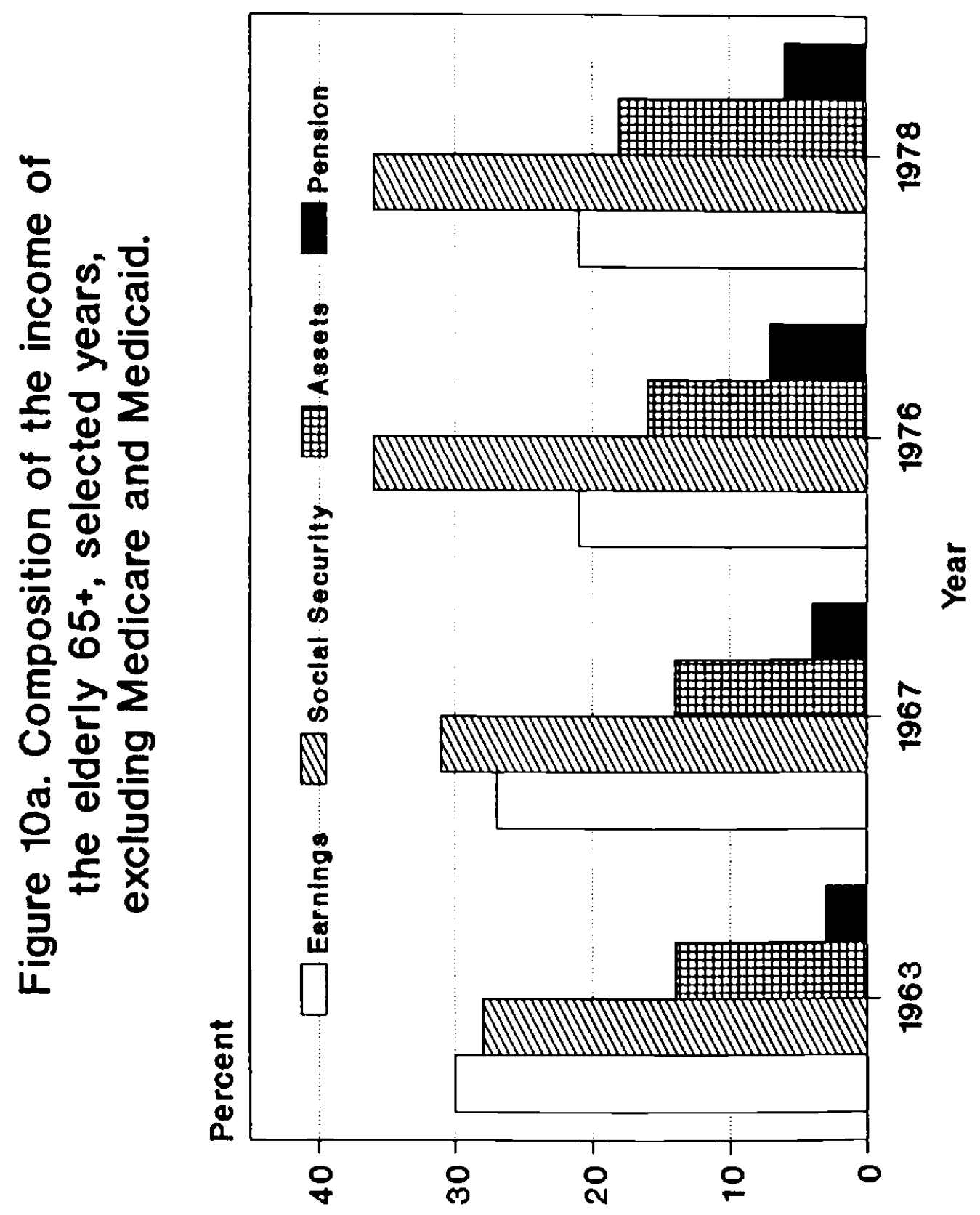



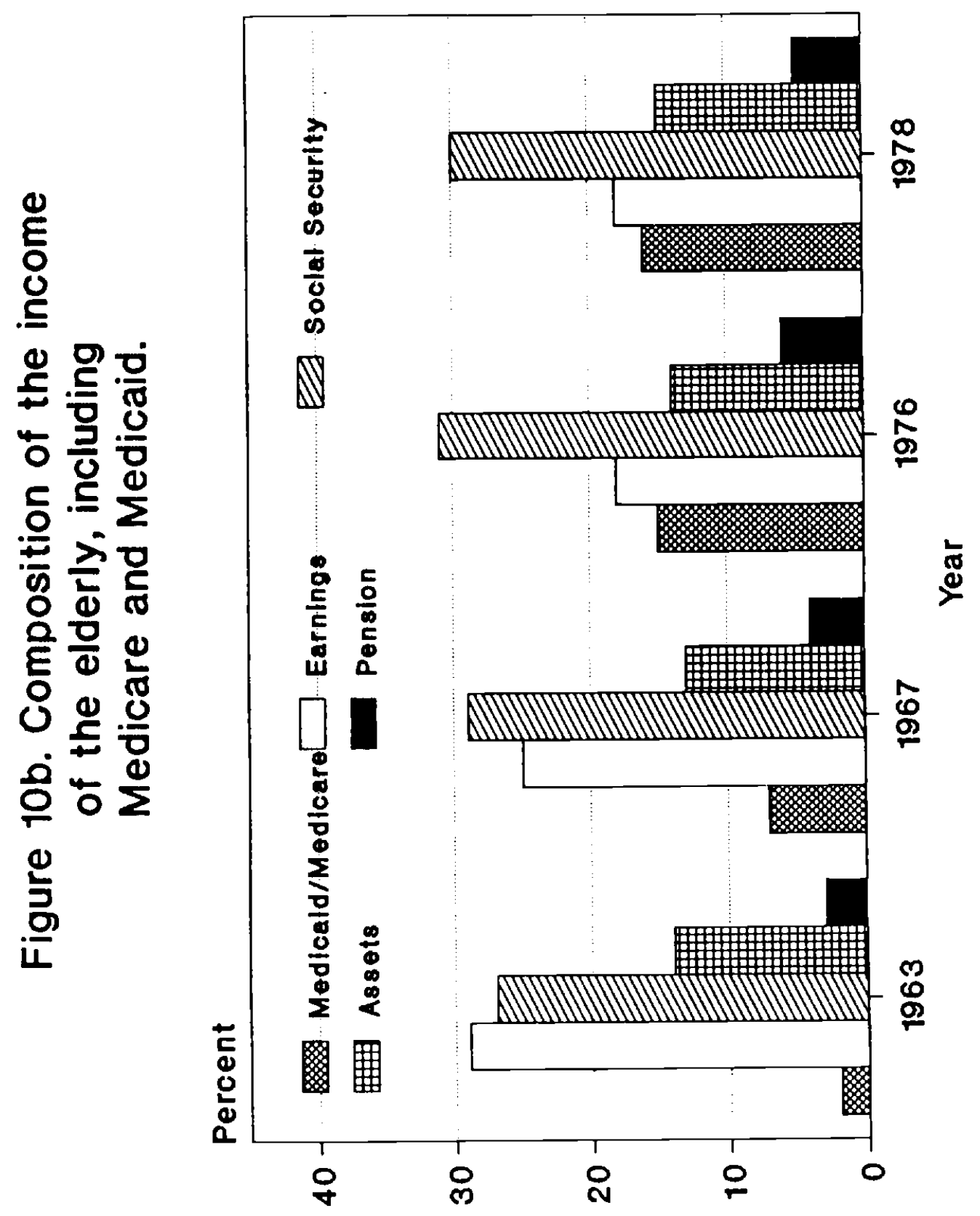
proportion of income from assets remained roughly constant. The Hurd and Shoven data are based on mean Income by category. Data by Venti and Wise, based on median income by category, make it clear that the vast majority of the Income of most elderly families comes from Soclal security and pension benef1ts. (See f1gures $6 a-6 c$ above.)

\section{Rersonal Saving.}

Changes in personal aving may also affect retirement decisions. Personal saving declined from 3 to 6 percent of disposable private income in the 1950 s to around 1 percent in the early 1980s, based on computations made hy summers and Carroll [1987) and reproduced in figure 11. These numbers are adjusted for Inflation and exclude saving by employers through defined benefit pension plans. 9 Without the inflation adjustment, the downward trend begins only after 1973. It 1s clear from papers by Vent1 and wise $[1987,1989\}$, for example, that there is a very large range in personal saving rates, with a large proportion of the population saving virtually nothing except in the form of housing equity. Thus the extent to which the aggregate data reflect a reduction in saving that could impinge on the retirement decisions of an Important proportion of employees is not clear. In any case, less personal saving, holding other income sources constant, would typically be associated with later retirement, clearly not the dominant force in the current trend.

7. Summary.

The trends discussed above are summarized in Figure 12. The labor force participation of older Americans has declined dramatically since 1940. Social

\footnotetext{
${ }^{9}$ The National Income Accounts include firm contributions to defined benefit pension plans under "personal saving." Inflation adjusted saving is measured saving, minus the inflation rate (the GNP deflator) times net interest bearing assets.
} 
(30)

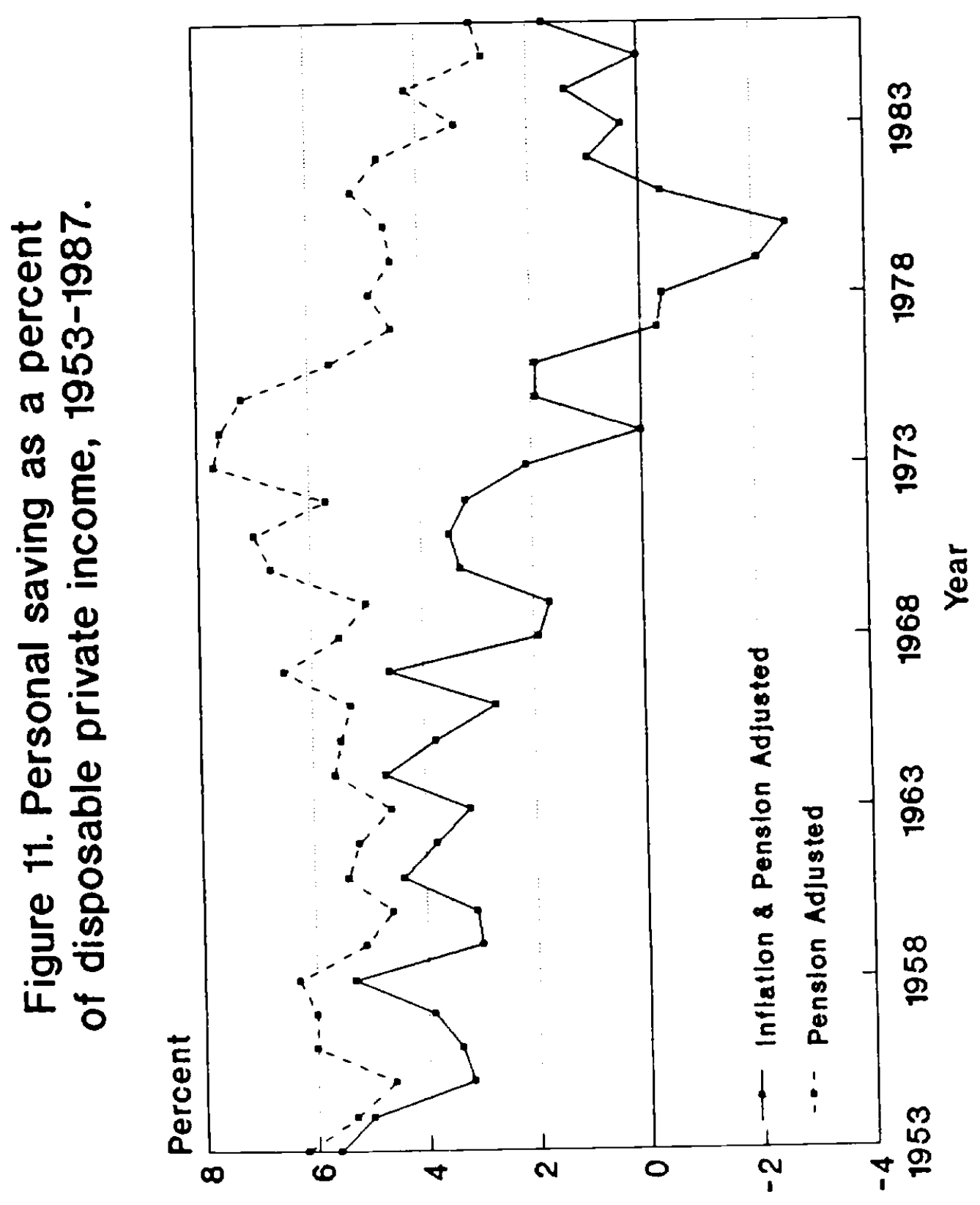


(31)

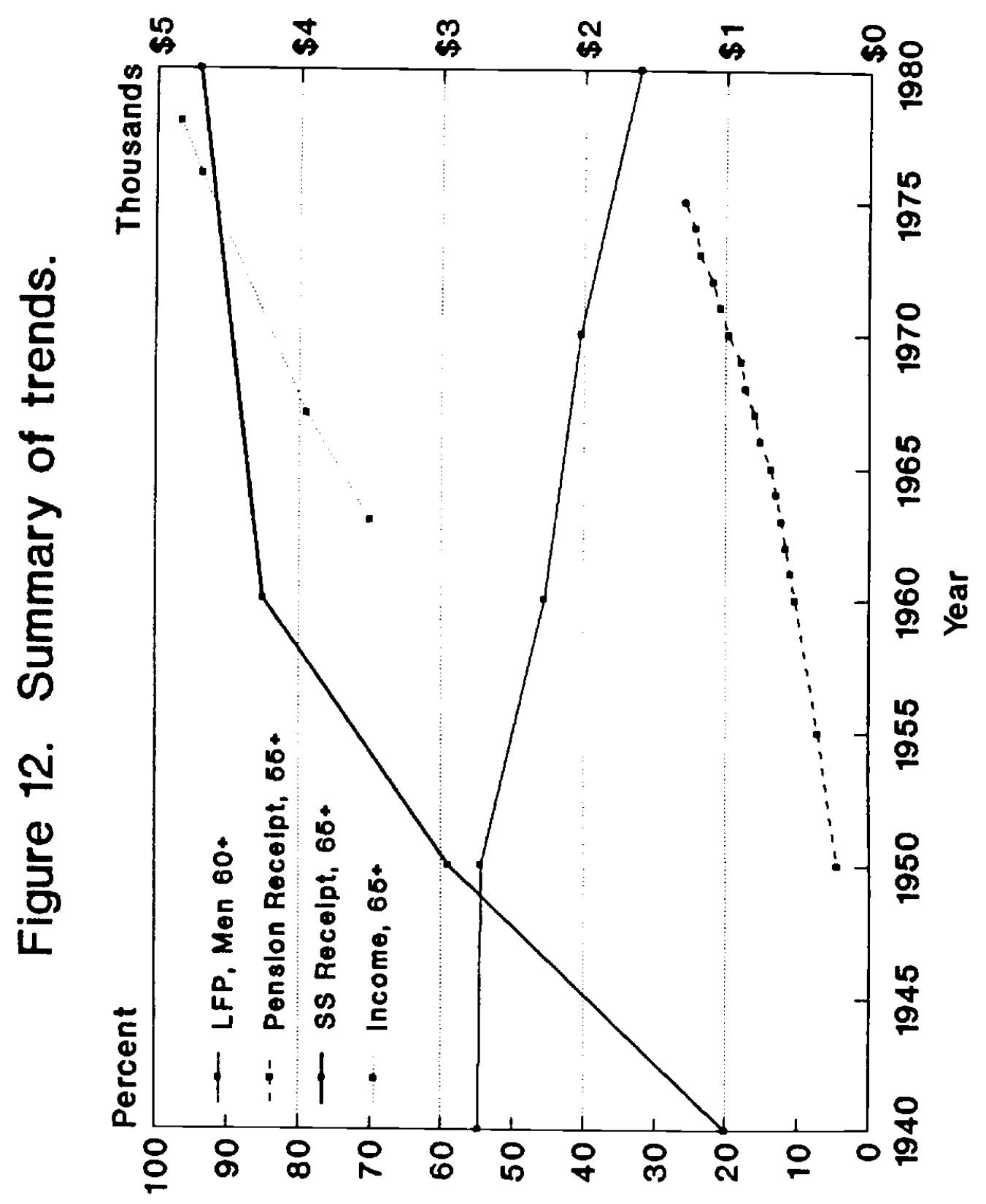


Security and pension benefits have become the major source of Income for the majorlty of older persons, and the total income of persons over 65 has Increased enormously, over three fold between 1963 and 1978 alone. (Real annual earnings of the typical employee are about the same now as they were in the early 1960s.) These forces have clearly dominated longer ilfe expectancy and lower pereonal saving that would be expected to prolong labor force participation. In addition, fall in real wages elnce 1970 may have contributed to earlier retirement in more recent years. Without some change In labor force participation rates of older persons, the prospect is that a smeller segment of working persons will support an increasingly larger group of retirees.

\section{The Incentive Effecte of Publlc and Priyate Retroment Plans.}

The foregoing discussion highlights the correlates of the reduction in the labor force participation rates of older Amerlcans, and suggests the conclusion that the reduction was induced by the introduction of $\mathrm{SS}$ and $\mathrm{f}$ irm pension plans. The Implication is that the adoption of public and private entitlements to retirement benefits made early retirement possible; it Increased the Income avallable to support retirement consumption. The discussion below emphasizes the incentive effects inherent in the provisions of public and private plans, Independent of the retirement wealth that they represent.

The 1980 s have witnessed a marked shift in government pollcy toward promoting the labor supply of the elderly. The government has virtually eliminated mandatory retirement and it has scheduled a gradual increase in the Soclal Security retirement age from 65 to 67 . It has limited somewhat the 
Social Security earnings test that reduces Social Security benefits for "retired" workers earning more than an "exempt amount;" It eliminated the earnings test after age 70 , and it is increasing the actuarial incentive to delay the recelpt of Social Security benefits beyond age 65 .

The change in the government policy is responsive to the major demographic swing that is underway and its important implications for retirement finances in the next century. Given Soclal Security's pay-as-yougo method of finance, the profected increase in the ratio of beneficlaries to contributors means either ignificant cuts in future benefits or significant future increases in the Soclal Security payroll tax.

Reversing the trend toward early retirement represents an important altornative for addressing the demographic transition. Additional labor supply of the elderly would relleve Social Security's finances as well as offoet a potential shortage in the supply of labor relative to that of other productive factors. In addition, it is argued that for many elderly prolonging their labor force participation would mean more fulfilling 11 ves.

What has gone largely unrecognizec is that, notwithstanding recent changes in Social Security regulations intended to prolong work, private pension plan provisions operate powerfully in the opposite direction. The most prominent theoretical explanations for the firm behavior rest on the proposition that the efficient structure of the age-wage profile is such that older workers are pald more than their worth to the firm and must therefore be encouraged to retire. (See Lazear [1979], for example.) Whether this is in fact the reason has not been demonstrated. Conversations with pension managers reveal that in some instances the incentives of the plans are not fully understood and many plans have been introduced without consideration of 
their effects on retirement. Some special early retirement incentives (temporary "window" plans) have been introduced to relieve the firm of older workers so that younger workers could be promoted, or simply as a means of reducing the size of the firm's workforce.

Many researchers have pointed to the Social Security system's high benefit levels and work disincentives as a major contributor to the continuing trend towards early retirement and a great deal of research has focused on the - ffect of Social Security benefits on labor force participation. Recent examples are Blinder, Gordon and Wise [1980], Burkhauser [1980], Hurd and Boskin [1981], Burkhauser and Quinn [1983], Burtless and Moffitt [1984], Hausman and Wise [1985], Burtless [1986], and Gustman and Steinmeler [1986]. WIth few exceptions - Hurd and Boskin [1981) and, to some oxtent, Hausman and Wise [1985] - these studies attribute only a modest portion of the early retirement trend to the effect of Soclal Security provisions, although the findings may reflect, to some degree, problems of misspecification in accounting for its effects. In contrast, there has been very little work relating retirement behavior to the retirement incentives provided by pension plans. 10 The apparent reason for this neglect has been the difficulty in obtaining data that combine the retirement choices of older workers with information about their past earnings and the specific provisions of their pension plans. 11

${ }^{10}$ The most closely related work considers the effect of pension plans on job mobility (Clark and McDermed [1987], Gustman and Steinmeier [1987), Allen, Clark, and McDermed (1987), and Allen, Clark, and McDermed (1988)), but not retirement.

11 Exceptions are Burkhauser [1979], Flelds and Mitchell [1982], Lazear [1983], Kotlikoff and Wise [1987], and Hogarth [1988]. 
More recent work of Kotlikoff and W1se [1985, 1987, 1989], Stock and wise [1988, 1989], and Lumsdaine, Stock, and wise [1989] suggests that the provisions of private pension plans are typlcally much more important than SS provisions as determinants of the retirement behavior of workers covered by such plans. Their detalled analysis of the provisions of private defined benefit pension plans, which account for roughly three quarters of all pension plan reciplents. Indicates that a large proportion of these plans provide very large incentives to retire early. Virtually all defined benefit plans Incorporate stiff financial penalties for working past the age of 65 , and a very sizable fraction have similarly stiff penalties for working past the plan's early retirement age, often as young as 55. Similar evidence 1s presented by Bulow [1981], Lazear [1983], Clark and McDermed [1984], Flelde and Mitchell [1984], and Frant and Leonard [1987]. Working an additional year often involves losing. In expected present value of future pension benefits, an amount equivalent to half a year's non-pension earnings, if not more. These retirement incentives in many, if not most, instances are signiflcantly greater than those ascribed to Social Security. We consider first the incentive effects inherent in the sS rules, and then the incentive effects of private pension plans.

\section{A. Soctal Security.}

The ss benefit amount is based on past individual earnings, although the relationship between benefits and earnings is not linear. Benefits are a much larger proportion of the past earnings of low-wage than of high-wage workers. The Initial benefit is based on nominal earnings Indexed to age 60 dollars using the Consumer Price Index (CPI). After retirement (recelpt of benefits), the benefits are indexed to the CPI. The SS normal retirement age 1s 65 . But 
benefits can be taken as young as 62 , with the benefit amount actuarially reduced to reflect the Increase in the expected number of retirement years over which benefits will be received. That is, if the benefit entitlement is not changed because of a change in earnings, the expected present value of future benefits is the sane Irrespective of the age, between 62 and 65 , at which the benefits are first recelved. After age 65, however, the Increase in the benefits 1 e much less than actuarlal. It is now 3 percent per year, but was only one percent per year unt1l 1981.12

The easiest way to understand the incentive effects of the benefit - tructure 1s to consider the relationshlp between the present value of future benefite and the age of retirement. Such relationships are shown in figures 13. for two representative workers, one a low-wage and the other a high-wage employee. The top part of the graph represents nominal earnings by age (age 50 earnings are in 1980 dollars). The bottom part of the graph represents the accrual of SS wealth (SSW). It is the change in the present value of SS beneflts between one year and the next. That $1 s, \operatorname{SSA}_{t}-\mathrm{SSW}_{t}-\mathrm{SSW}_{t-1}(1+\mathrm{r})$, where in this case $r$ is a nominal discount rate taken to be 9 percent. Thus the figure represents two forms of compensation: one is wage earnings, the other is the increase in the entitlement to future ss benefits.

Social Security accrual is a small proportion of wage earnings for the high-wage worker, but can be a signiflcant proportion for the low-wage worker, as shown in figure 13b. It is about 6 percent of the wage earnings of the low-wage worker at age 50 and increases to almost 10 percent at age 62 . If

12 Although the change from 1 percent to 3 percent was the result of a 1977 law, It applied to those who would be 65 in 1981 and later years. 
(37)

Figure 13a. Social Security accrual and earnings, representative low and high wage workers.
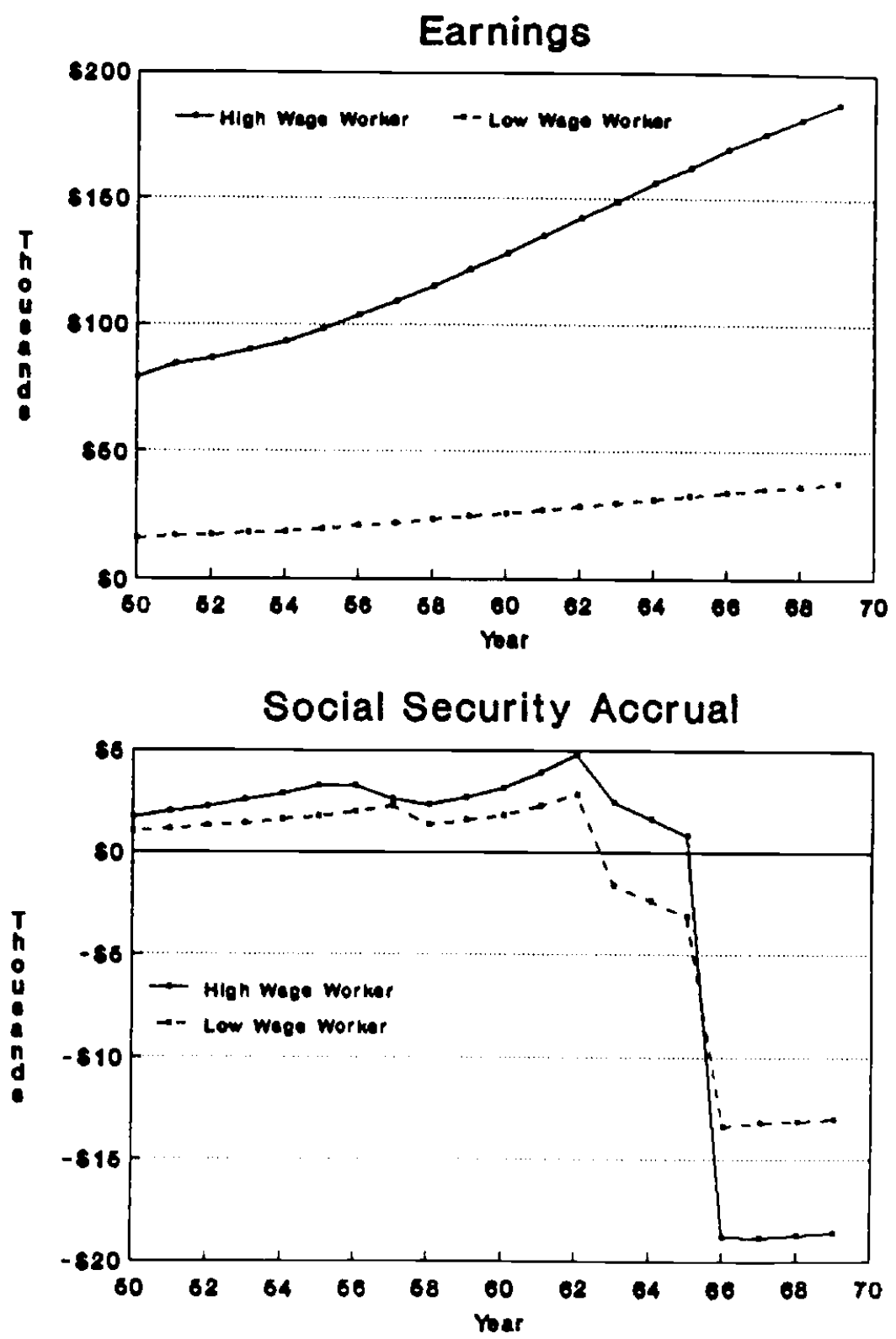


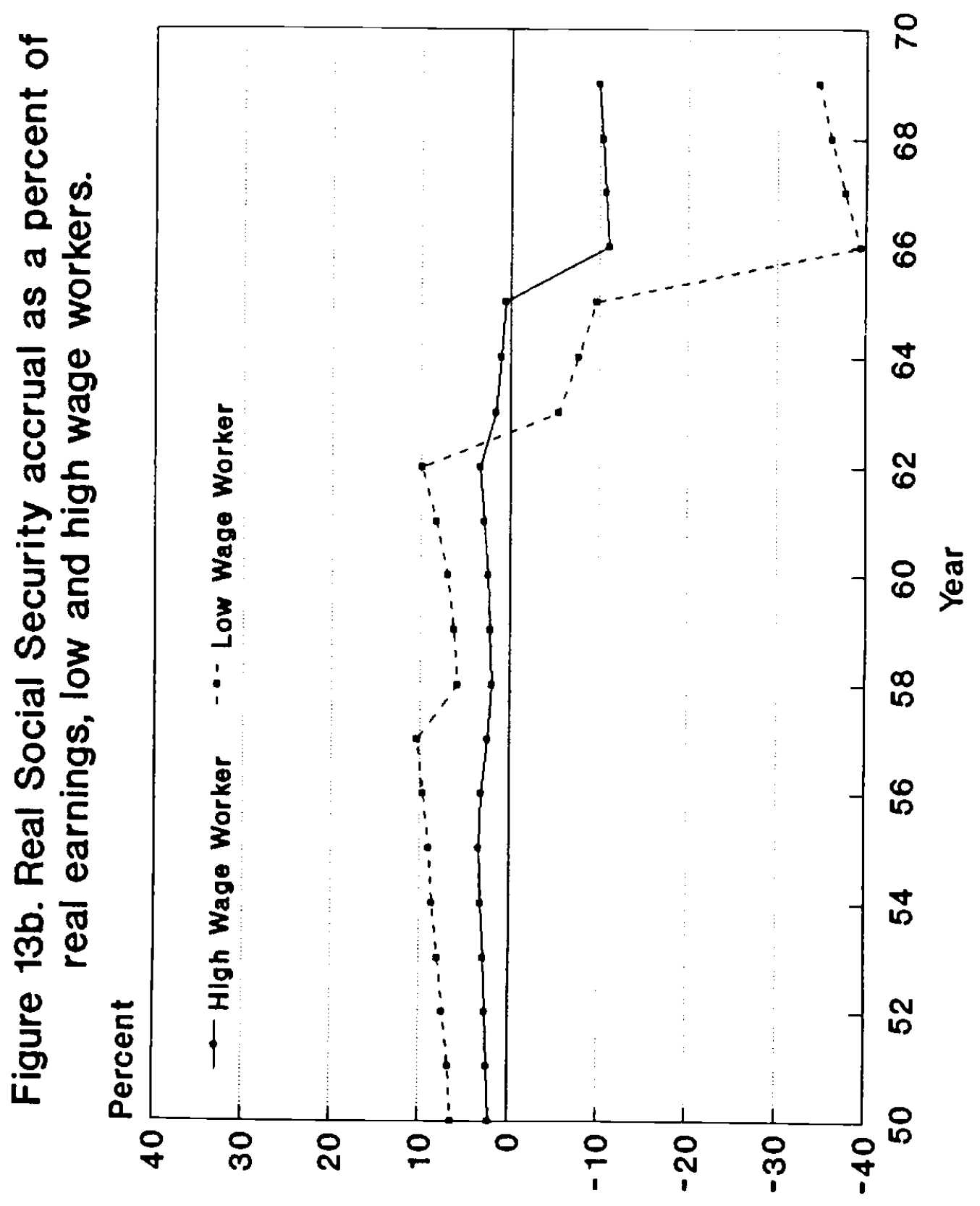


the low-wage worker continues to work from 62 to 65 , the accrual is nepative, (10 of the wage at 64 ). The loss in the present value of ss benefits would be about 39 percent of wage earnings if the person continued to work past age 65. Thus the reduction in total wage and SS compensation between 62 and 66 would be about 50 percent, were the low-wage worker to continue to work. The reduction in total compensation for the high wage worker would be about 14 percent. Thus the SS inducement to leave the labor force at age 65 is inversely related to wage earnings.

\section{B. Eirm Pensions.}

Roughly three quarters of all persons participating in private pension plans are enrolled in defined benefit plans where benefits are determined according to a specifled formula. The remainder are enrolled in plans where benefits are directly related to contributions made on behalf of the employee and to the performance of the plan's investment portfollo. Because most workers are covered by defined benefit plans and because they are likely to have the greatest effects on labor market behavior, the discussion here emphasizes the incentive effects of this type of plan. The evidence is presented in three sections. The first section discusses the "average" incentives of a large number of plans. The second section discusses the incentives of the plan of a single large firm and relates these incentives to departure rates from the firm. The third section discusses a new econometric model of retirement and simulations based on the model.

\section{The Incentive Effects of Typical Plans.}

Kotlikoff and Wise [1985 and 1987] considered the retirement incentive effects inherent in typical defined benefit plans and have analyzed the provisions of a large number of firm plans. As with Social security, it is 
easiest to exhibit the potential retirement incentive effects of defined benefit pension plans by describing the accrual of vested benefits. Figure 14 is taken from Kotlikoff and wise [1987]. It shows the average accrual rates (weighted by plan membership) for U.S. defined benefit plans with selected early and normal retirement ages. The pension accrual in a year is the Increase (or decrease) in the expected discounted value of future pension benefits that results from working that year. It is the value of deferred compensation analogous to current wage compensation. Pension accrual is shown as a percent of wage compensation (the accrual ratio or accrual rate). The data come from a random samplc of approximately 2500 plans from the Buraai of Labor Statistics Level of Benefits Survey. ${ }^{13}$ For each plan, accrual rates are calculated assuming average wage-tenure profiles in the industry and occupation to which the plan pertains, based on current population survey data. 14

Consider first plans with early and normal retirement at the same age, 55, a plan stipulation that is common in the transportation industry, for example. The average decline in the rate of pension wealth accrual at 55 is equivalent to about 30 percent of wage earnings. If the typical person covered by such a plan were to continue to work through age 65 , pension accrual would be negative and equivalent to approximately 30 percent of wage earnings. Whereas at age 54 the pension benefit accrual is equivalent to about 30 percent of wage earnings, after age 65 continued work means a loss in

${ }^{13}$ Similar calculations have been made by Lazear [1983] based on the Bankers Trust Survey of large pension plans.

${ }^{14}$ See Kot 1 koff and Wise [1985]. 


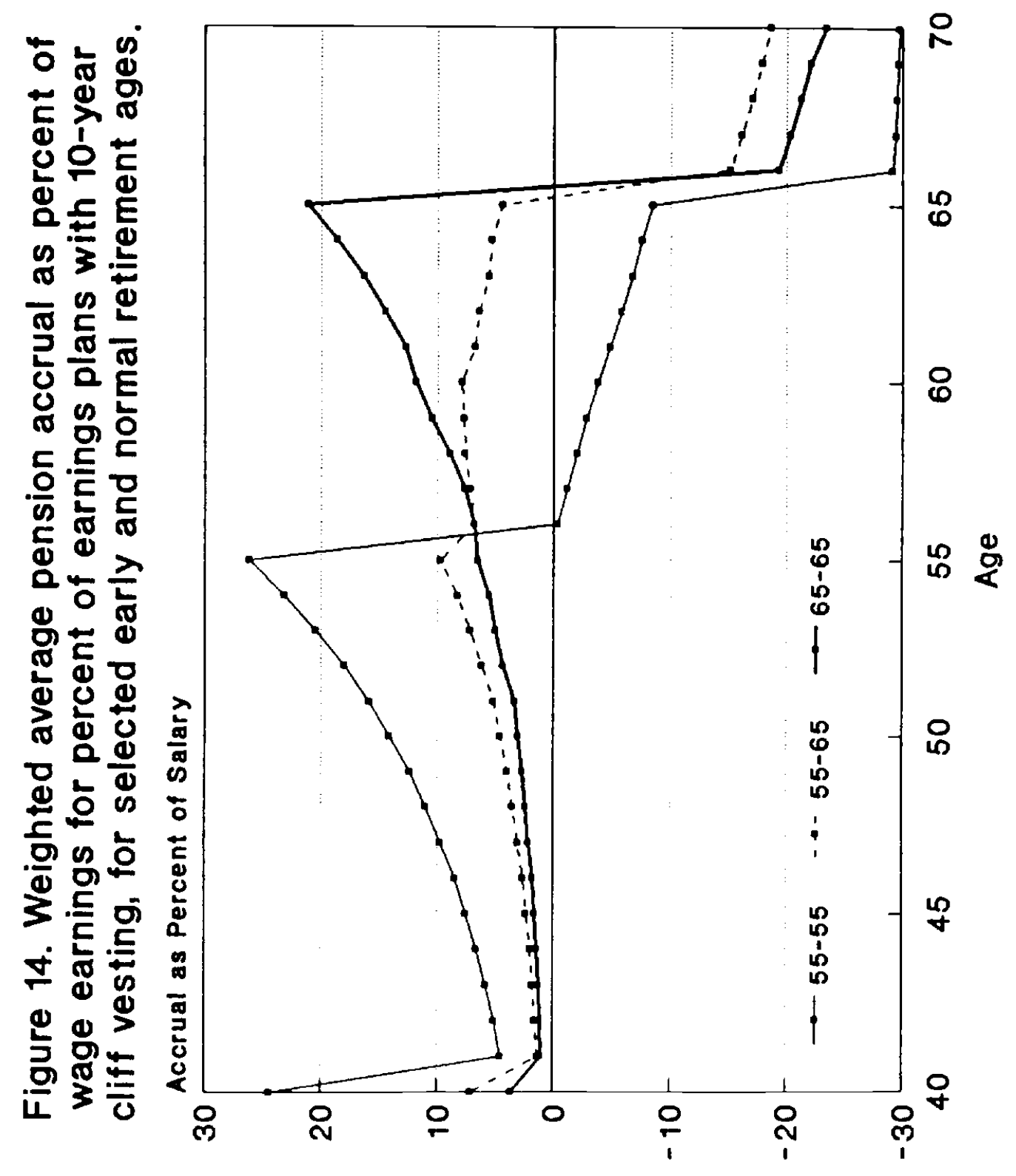


pension wealth equivalent to about 30 percent of wage earnings. Thus, between these two ages, the decline in the rate of pension wealth accrual is equivalent to a 60 percent wage reduction!

The more common plans with early retirement at 55 and normal retirement at 65 typically exhibit an increase in pension wealth accrual to age 55 with a decline thereafter. Again, continued work past age 65 is associated with a substantial loss in pension wealth, with the decline in accrual equivalent to approximately 20 percent of wage earnings. The pension wealth of persons covered by plans with early and normal retirement both at 65 increases continuously until 65 and then declines by approximately 40 percent, from a positive accrual of about 21 percent of salary to a negative accrual of about 19 percent.

Thus, based on industry wide earnings profiles, continued employment with the plan sponsor after the age of early retirement and, in particular, after the age of normal retirement, typically involves a substantial reduction in total annual compensation because of declines in pension wealth accrual.

While figure 14 highlights the average characteristics of plans, it is important to understand that there is a very wide range in plan provisions, even among plans with the same early and normal retirement ages. This is demonstrated in figure 15, also taken from Kotlikoff and wise [1987]. The figure shows average accrual rates for the 513 plans of figure 14 with early retirement at 55 and normal retirement at 65 , together with upper and lower 5 percentile levels. The lower 5 percentile points for any age group is that accrual rate such that 5 percent of plans have accruals below the level. The . upper 5 percentile point is defined analogously. Consider the accrual ratio at vesting. While the average vesting ratio for this sample is .071 , the 
(43)

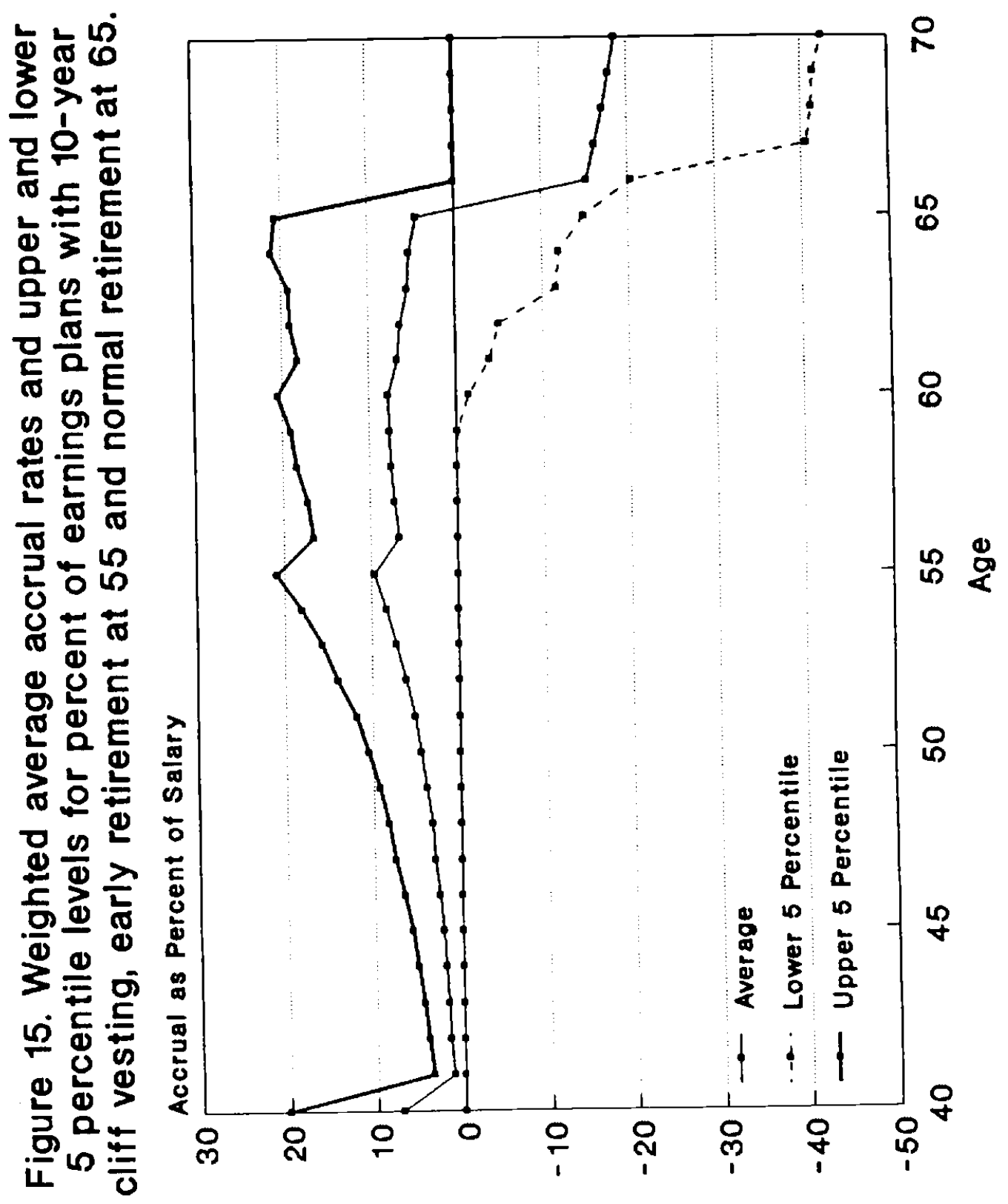


median .021 , the maximum 1s .383, and the minimum is zero. The ratio at the lowest five percentile point is 0 , while it is .201 at the largest five percentile level. A simflarly large dispersion in annual accrual ratios is Indicated for each of the ages 40 through 70 . The average accrual rates between ages 55 and 65 are positive, but for many plans the rates by 65 are very negative.

Thus while the average plan may provide positive pension accrual at a particular age, the accrual rate may be substantially negative for some plans. Even a small proportion of plans that provide a strong incentive to leave the labor force could have a very substantial effect on observed average labor force participation rates. Thus it is 1mportant to base judgments about the labor force participation incentive effects of pension plans on more than average accrual rates.

\section{The Plan of a Large Firm.}

Whether Incentive effects like those described above have an effect on retirement decisions is a second question. Kotlikoff and Wise [1985, 1989] have addressed this question by considering the relationship between pension plan provisions and retirement rates in large Fortune $500 \mathrm{firm}$. That work is summarized in this section. The analysis of the firm data shows a very strong relationship between the plan provisions and departure rates from the f1 rm.

a. The Plan. The plan normal retirement age is 65 ; the early retirement age is 55 . Vesting occurs after 10 years of service. The plan is Integrated with Social Security, so that the benefits are reduced (offset) by some proportion of SS benefits. Figure 16a summarizes the incentive effects inherent in the plan provistons. The figure shows the pension accrual between 
(45)

Figure 16a. Wage earnings, pension accrual, and Social Security accrual, representative person in Firm I.
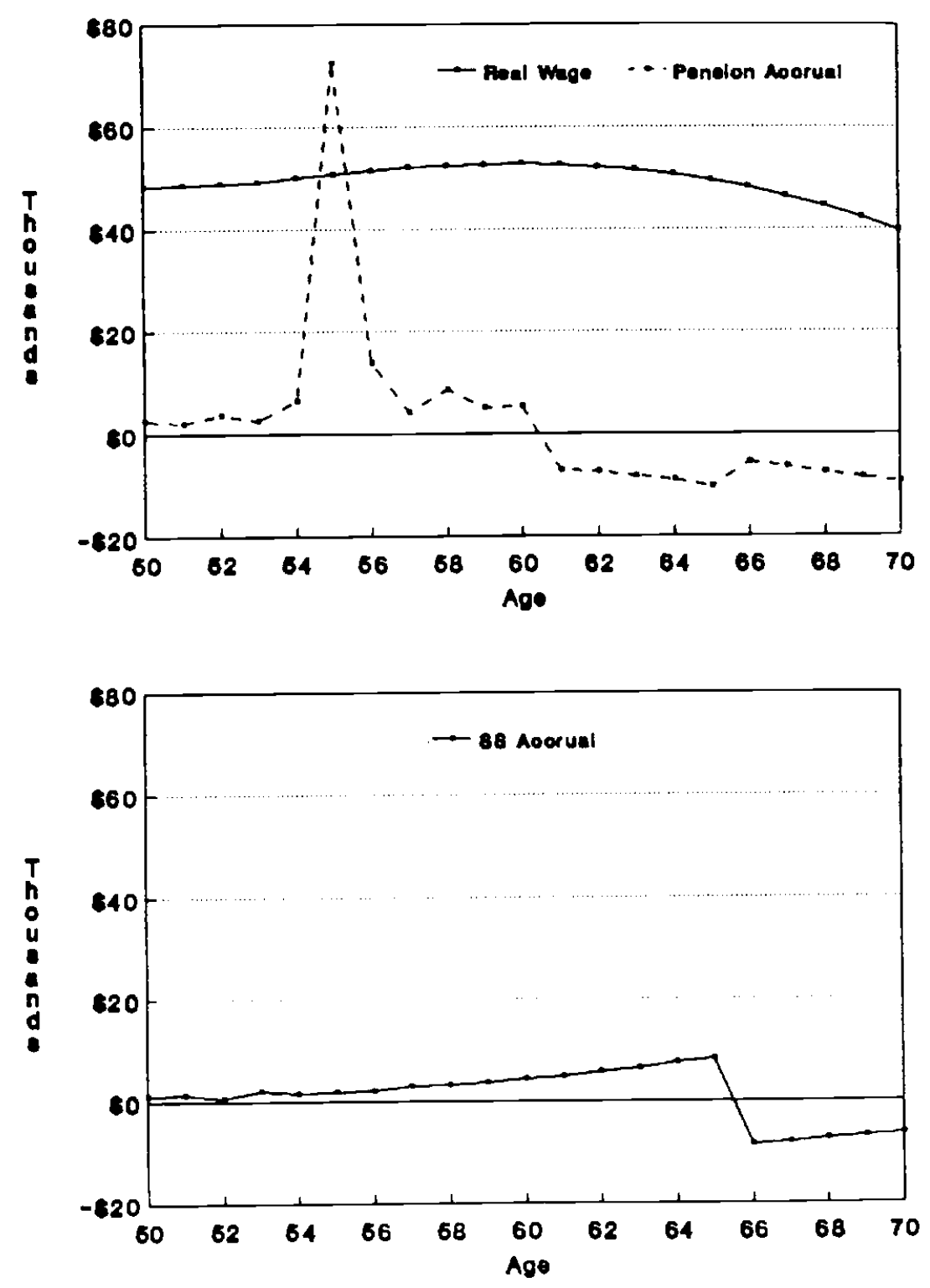


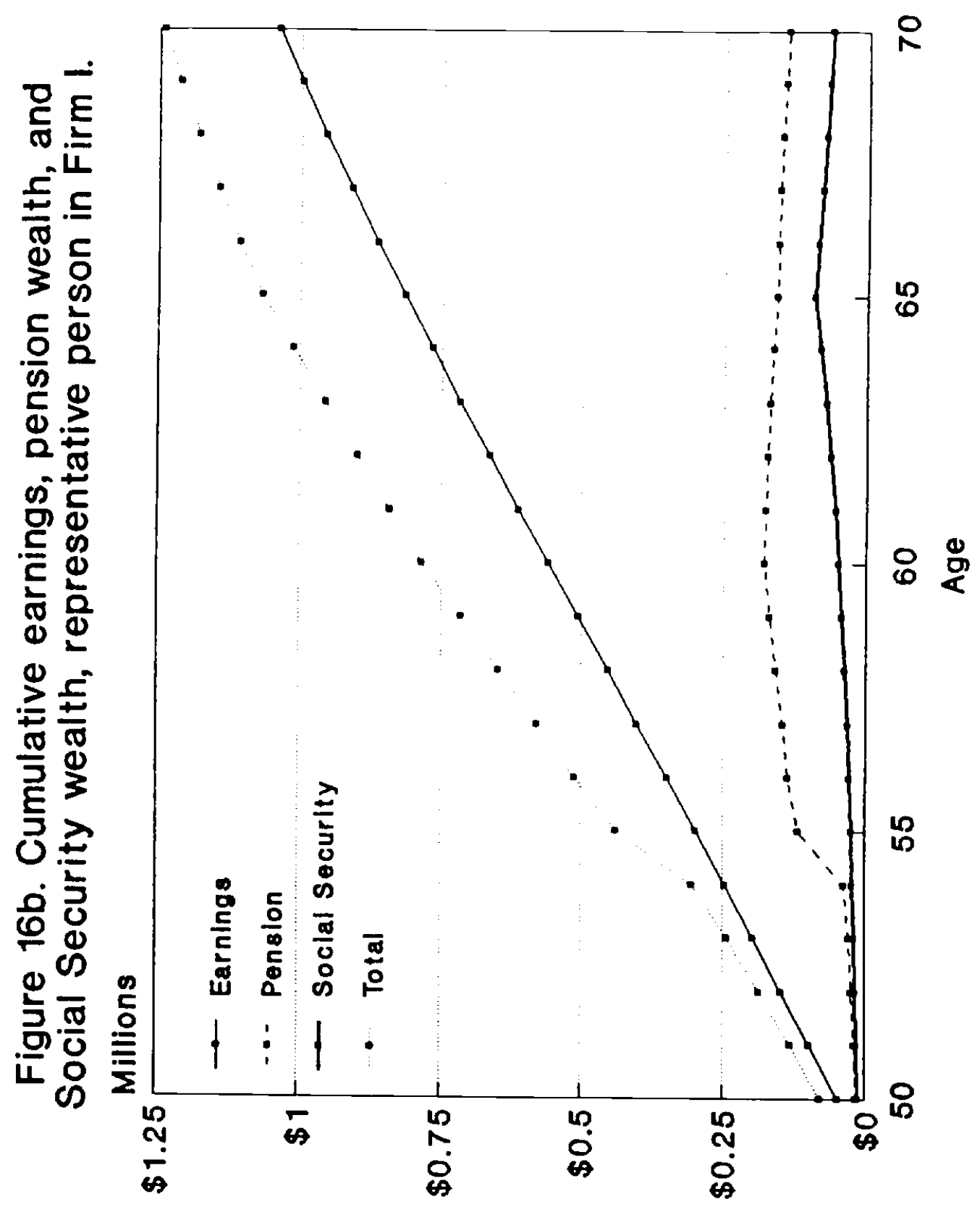


ages 50 and 70 of male managers hired by the firm in 1960, at age 30 . By 1980, they were 50 and had 20 years of service with the firm. The accrual of Social Security benefits and predicted wage earnings for each year are also shown. The wage predictions are based on actual average earnings of $\mathrm{firm}$ employees. All of the numbers are In real 1985 dollars.

At age 50, the typical male manager has wage earnings of about $\$ 48,446$ per year. Compensation in the form of pension accrual is $\$ 2.646$, or about 6 percent of wage earnings. If the manager were to retire at this age, he would be entitled to benefits at 65 , based on his earnings in the seven or eight preceding years. The benefits would not be avallable until age 65 , and thus have a relatively low present value at age 50 . Normal retirement benefits could be taken earlier, as early as age 55, but they would be reduced actuarially such that the present discounted value of the benefits remains unchanged. The reduction in the benefit would be just enough to offset the fact that benefits would be received for more years. 15

If the person remains in the firm until age 55 and then retires, however, benefits are available immediately, and the reduction In benefits for early retirement is less than the actuarial reduction. In addition, the worker who remains until age 55 and then retires is eligible to receive a supplemental benefit until age 65 equal to his Social Security offset. Thus there is a very large increase in pension wealth at age $55, \$ 72,527$, corresponding to the large spike in the graph. In effect, there is a bonus of $\$ 72,527$ for remaining in the firm from age 54 to 55 .

${ }^{15}$ Not accounting for any real rate of time preference. 
After age 55, pension accrual falls, to about 10 percent of the wage at age 60.16 Pension accrual is in fact negative beginning at age 61 . The loss in compensation between ages 60 and 61 is equivalent to a wage cut of about 14 percent. Between ages 61 and 65 the loss in pension benefits is equivalent to about 20 percent of annual wage compensation. If the worker has 30 or more years of service at age 60 , he is eligible for full retirement benefits; the early retirement reduction factors no longer apply. 17

Social Security accruals range from about $\$ 1,000$ to $\$ 8,000$ between age 50 and 65. After 65 , Social Security accrual becomes negative, about $-\$ 8,500$ at age 66. At 66 , the loss in private pension benefits and Social Security benefits together amounts to about 32 percent of wage earnings at that age. (For some groups of employees in the firm, the loss in pension and Social Security wealth together after age 65 is equivalent to 95 percent of wage earnings: If these employees continue to work, it is essentially without compensation.)

${ }^{16}$ The plan provisions stipulate that an additional year of service adds $\underline{2}$ percent to normal retirement benefits per year of service before age 55 , but only 1 percent per year of service after age 55 .

${ }^{17}$ Thus no increase in benefits will result for working another year from the application of one less year of early retirement reduction, as was the case before 30 years of service. In addition, for each year that benefits are not taken between ages 55 and 65 , the recelpt of benefits for a year without the Social Security offset (reduction) is foregone. This advantage is lost at age 65 . Thereafter, the loss in benefits from working an additional year is smaller because this opportunity is no longer avallable; it was only avallable unt1l age 65 . The accruals also depend to a small extent on the updating of the years used in the calculation of "final" earnings. "Final" earnings are used to determine the pension benefit. 
The data in figure 16 are shown in the standard budget constraint form In figure 16b. Total compensation, including wage earnings, Social Security wealth, and pension wealth, is graphed against age, beginning at age 50 .

There is a discontinuous fump in the graph at age 55, the age at which early retirement benefits are avallable on an advantageous basis.

b. The Firm Departure Rates. Departure rates by age and years of service suggest the effect of pension plan provisions on retirement. They are shown for salesmen by age and years of service in table 1 below.

Table 1. Departure Rates for Salesmen by Age and Years of Service

\begin{tabular}{|c|c|c|c|c|c|c|c|}
\hline & & & eears of & Service & & & \\
\hline Are & $<10$ & $11-15$ & $16-20$ & $21-25$ & $26-30$ & $31-35$ & $36+$ \\
\hline$<50$ & 19 & 9 & 5 & 4 & 3 & -- & $\cdots$ \\
\hline $50-54$ & 14 & 7 & 4 & 3 & 3 & 2 & 0 \\
\hline 55 & 11 & 14 & 9 & 11 & 12 & 15 & $\cdots$ \\
\hline & & 13 & $\ldots$ & $\ldots$ & $\ldots$ & $\ldots$ & \\
\hline 60 & 11 & 12 & 14 & 19 & 14 & 29 & 35 \\
\hline 61 & 13 & 12 & 13 & 13 & 19 & 32 & 28 \\
\hline 62 & 12 & 27 & 32 & 38 & 36 & 52 & 35 \\
\hline 63 & 20 & 28 & 33 & 36 & 47 & 48 & 56 \\
\hline 64 & 0 & 37 & 36 & 30 & 36 & 38 & 28 \\
\hline 65 & 34 & 56 & 51 & 50 & 49 & 47 & 43 \\
\hline 66 & 17 & 28 & 10 & 34 & 18 & 16 & 12 \\
\hline 67 & 20 & 16 & 25 & 21 & 8 & 5 & 18 \\
\hline
\end{tabular}

The yearly departure rate is the proportion of those employed at the beginning of the year that retires - - more strictly speaking, leaves the firm -- during the forthcoming year. Several aspects of the data stand out: (1) Before 55 departure rates are typically around 3 percent for vested employees; they are substantially larger for those with less than ten years of service, who are 
not vested. At 55, the early retirement age, they jump to 10 percent or more, but only for vested employees, those with at least 10 years of service. It is Important to notice that the departure rates stay at that level until age 60 , when there is another jump in the rate of departure. (2) At age 60, the departure rates increase very precipitously especially for persons with over 30 years service. For this group full benefits are avallable because there is no longer an early retirement reduction according to the plan's rules. For this group subsequent pension accrual is negative. (3) When Social Security benefits become available at 62 , the departure rates again increase very sharply, but oniy for those who are vested in the firmplan. (4) Finally, there is a large increase in departure rates at 65 , the ss normal retirement age. Both pension and SS accruals are negative if the employee continues to work beyond age 65 .

To understand the potential importance of the early retirement benefits, suppose that if 1 t were not for this inducement, the departure rates would remain at 3 percent unt 11 age 60 instead of the 10 or 12 percent rates that are observed. Departure at 3 percent per year means that 14 percent of those who were employed at 55 would have left before age 60; at 11 percent per year, 44 percent would leave between 55 and 59.

Cumulative departure rates for all employees are shown in table 2 below for three years, together with the rates by age. The cumulative rates are one minus the percent who have departed. 
Table 2. Cumulative and Yearly Departure Rates by Calendar Year. Years of Service, and Age

Yearly

\begin{tabular}{|c|c|c|c|c|c|c|c|}
\hline \multirow{2}{*}{ Age } & \multirow{2}{*}{$\frac{8-10 \text { YOS }}{1980}$} & \multicolumn{3}{|c|}{$11+Y O S$} & \multicolumn{3}{|c|}{$11+Y O S$} \\
\hline & & 1981 & 1982 & 1983 & 198 & 1982 & 1983 \\
\hline 50 & 7 & 3 & & & 97 & 97 & 97 \\
\hline$\$ 1$ & 9 & 3 & & & 94 & 94 & 94 \\
\hline 52 & 3 & 5 & 5 & 5 & 89 & 89 & 89 \\
\hline 53 & 0 & 4 & 4 & 4 & 85 & 86 & 86 \\
\hline 54 & 4 & 3 & 4 & 2 & 83 & 83 & 84 \\
\hline 55 & 5 & 11 & 12 & 10 & 74 & 73 & 75 \\
\hline 56 & 4 & 12 & 14 & 10 & 66 & 63 & 68 \\
\hline 57 & 2 & 9 & 12 & 11 & 60 & 56 & 61 \\
\hline 58 & 5 & iû & 14 & 12 & 54 & 48 & $j 4$ \\
\hline 59 & 2 & 11 & 20 & 10 & 48 & 38 & 48 \\
\hline 60 & 4 & 17 & 29 & 17 & 40 & 27 & 40 \\
\hline 61 & 0 & 17 & 32 & 18 & 33 & 18 & 33 \\
\hline 62 & 8 & 36 & 48 & 31 & 21 & 10 & 23 \\
\hline 63 & 14 & 37 & 54 & 37 & 13 & 5 & 14 \\
\hline 64 & 11 & 29 & 49 & 26 & 10 & 2 & 11 \\
\hline 65 & 25 & 53 & 58 & 45 & 5 & 1 & 6 \\
\hline
\end{tabular}

Given employment at age 50, the cumulative rates show the percent still

employed at older ages. Based on the 1981 and 1983 departure rates, only 48 percent of those employed at 50 would still be employed at 60 , and then 17 percent of these would leave. Only 10 percent would remain until age 65 , and then about 50 percent of these would leave.

These data also show the effect of a special early retirement incentive (a "window plan") that was in effect in 1982 only. For employees who were eligible for early retirement in 1982, the incentive program provided a bonus of up to one year's salary. It is clear that the effect of the incentive was large: while the departure rates for 1981 and for 1983 are virtually identical, the 1982 rates were much higher. For example, the departure rate 
for 60 year olds was 17 percent in 1981 and 1983, but 29 percent in 1982 . Of those employed at age 50, 40 percent would still have been employed after age 60 based on the 1981 and 1983 departure rates. Only 27 percent would remain after age 60 based on the 1982 rates. Even under the normal plan, only 10 percent of those employed at age 50 would still be employed at 65 . Only 2 percent would remain until 65 with the special incentive.

c. An Option Value Model of Retirement.

The discussion above demonstrates the large incentive effects inherent in the provisions of defined benefit pension plans and shows that these Inccntives have very slibstantial effects on firm retiremelit fard oblei departure) rates. An additional goal of research in this area is to predict the effect on retirement rates of changes in firm pension plan and ss provisions.

i. The Model. Two basic approaches, in addition to least squares regression, have been used in recent years to analyze retirement behavior. The first is the method of estimation developed to analyze the choices of individuals who face discontinuous or kinked budget constraints. The central feature of this method is a lifetime budget constraint analogous to the standard labor-leisure budget constraint, but with annual hours of work replaced by years of labor force participation, and annual earnings replaced by cumulative life-time compensation. The optimal age of retirement is determined by a utility function defined over years of work (post-retirement years of leisure) and cumulative compensation. A careful application of this approach to retirement is by Burtless [1986], who analyzed the effects of changes in Social Security benefits on retirement. 18 While appealing in many

${ }^{18}$ An analogous model was used by Venti and Wise [1984] to describe the rent paid by low income families faced with discontinuous budget constraints. Earlier papers that develop these techniques are Hausman and Wise [1980] and Burtless and Hausman [1978]. 
respects, this procedure has an important drawback. It implicitly assumes that individuals know with certainty the opportunities - like wage rates . that will be available to them in the distant future. The hazard model is the second approach. As implemented to date it is essentially a reduced-form technique designed to capture the effects on retirement of movements in variables such as Social Security wealth. Implementations of the hazard model have not been as "forward looking" as the non-linear budget constraint specifications. 19 On the other hand, unexpected shocks, like sudden changes in earnings, enter the analysis ver; naturally.

The Option Value Model as specified by Stock and Wise [1989] incorporates the advantages of both of the approaches described above. It allows updating of information, as does the traditional hazard model, but also considers potential compensation many years in the future, as does the nonlinear budget constraint approach. 20 The key ideas of the model can be summarized briefly.

${ }^{19}$ Thus in Hausman and wise [1985), for example, changes from the current period to the next, in earnings, pension wealth, and the increment to pension wealth, are allowed to affect the decision to retire in the next period, but expectations of these values several years hence are not.

20 Antecedents of the Stock and Wise model begin with Lazear and Moore [1988], who argue that the option value of postponing retirement is the appropriate variable to enter in a regression equation explaining retirement. Indeec it was their work and analys is of military retirement rates by phillips and Wise [1987] that motivated Stock and wise to pursue this approach. The Stock and Wise model is close in spirit to the stochastic dynamic programming model of Rust [1989]. Rust's [1989] model poses substantially greater numerical complexity than the stock and Wise model and has not yet been estimated for retirement. In principle, he observes not only the individual's retirement age, but subsequent consumption decisions as well. Thus his model allows the individual to optimize over age of retirement and future consumption jointly. The individual's decision is modeled as the solution to a stochastic dynamic programming problem. As in the stock and Wise case, the individual's expectations are conditioned on current known variables such as income. The idea is to recover the parameters of a utility function specified in terms of these choice variables. In practice, though, he uses income to 
It is intended to capture an important empirical regularity, the

describe consumption (Rust (1988)), with a value function similar to that of stock and wise, specified in terms of income. To simplify the solution to the dynamic programming problem in his model, he assumes that random unobserved individual components are independent over $t$ ime, whereas stock and wise allow such terms (representing differences among individuals in health status, desire for leisure, and the like) to be correlated. In short, Rust has described a solution to a more complicated choice than stock and wise, but with uncorrelated errors, whereas the stock and wise model is a solution to a less complex problem, but with correlated errors. A "dynamic programming" model of employment behavior has also been proposed by Berkovec and Stern [1988]. Berkovec and Stern's analysis is also in progress. They consider transitions amnng three employment states over time. To simplify the solution to their optimization problem, they assume that disturbance terms are uncorrelated over time, except for an individual-specific random effect. Their analysis is in terms of individual attributes like education, race, health status, and age. Government benefits like Social Security are not explicitly modeled, whereas these benefits, as well as firm pension benefits play the central role in the stock and wise analysis. Stock and wise estimate a discount, or weighting factor, whereas they obtain estimates of other parameters conditional on an assumed discount rate. Age itself is used explicitly to estimate retirement. Age is not a direct determinant of retirement in the standard version of the stock and wise model. This has important implications if the model is to be used to predict the effect of changes in firm pension plan or Social security provisions on retirement. Neither Rust nor Berkovec and Stern, however, have information on private pension plan provisions, the focus of the stock and wise analysis. The retirement decision rule proposed by stock and wise as an approximation to individual behavior is much simpler than the dynamic programming rule. A concomitant of this assumption is also much simpler econometric implementation than the burdensome calculations imposed by the dynamic programing rule. These simplifications reduce the computational requirements substantially while retaining the key forward-looking features of the dynamic programming approach. Of course both of these models are theoretical abstractions. The important consideration is which decision rule is the better approxtmation to the calculations that govern actual individual behavior. The answer to this question will have to await further analysis. Stock and wise show that the rule they assume predicts individual choices well; but the predictive validities of the alternative decision rules have not been compared. 
irreversibility of the retirement decision. Although it is not uncommon to work - at least part-time - after "retirement," it is rare to return to the job from which one has retired. The model focuses on the opportunity cost of retiring or, equivalently, on the value of retaining the option to retire at a later date. It has two key aspects. The first is that a person will continue to work at any age if the option value of continuing work is greater than the value of immediate retirement. In effect, the person compares the best of expected future possibilities - - the option value of continuing to work -with the value of retiring now. The second is that the individual reevaluates this retirement decision as more information about future earnings -. and thus future retirement benefits - becomes avallable with age. For example, a decline in the wage between ages 56 and 57 will cause the individual to reassess future wage earnings, and thus future pension beneftts and Social Security accrual as well. Thus retirement may seem more advantageous upon reaching 57 than it was expected to be at age 56. Retirement occurs when the value of continuing work falls below the value of retiring.

11. Simulations of the Effect of Changes in Pension and SS Provisions. To illustrate the potential to affect retirement behavior through changes in penston and SS provisions, three simulations from Stock and Wise [1988] and one from Lumsdaine, Stock, and Wise [1989] are discussed here.

(a). Increase the Firm Early Retirement Age from 55 to 60 . The effect of increasing the firm's early retirement age from 55 to 60 , leaving other provisions as they were, is shown in figure 17. Under the current plan 65 percent of those employed at 50 have left before age 60 . Only 42 percent 
would have left before age 60 if early retirement had been at 60 instead of 55. Only 13.6 percent of employees leave between 55 and 59 if early retirement is at 60 , whereas 45.5 percent leave between these ages under the current system. On the other hand, because the early retirement "bonus" is now farther in the future, more employees leave the firm between 50 and 54 . This is the result of the greater welght given to current versus future income. In short, many more workers would be employed between the ages of 57 and 65 if the early retirement age were 60 instead of 55 .

(b). Increase the SS Early Retirement Reduction Factor. Social Security benefits can be taken teginning at age 62, but the current Social Security rules include a benefit reduction of $5 / 9$ percent per month of retirement before age 65.21 The simulated effect of increasing the reduction factor to 1 percent per month is shown in figure 18. It is clear that the effect of this change is small relative to the effect of the change in the firm early retirement age. This is primarily because only a small fraction of firm employees are still working at age 62 , only 21 percent in the base case. The retirement rates of those still employed at age 62 , however, are considerably lower - about 14 percent - with the higher reduction factor. They are also lower at 63 . St111, the net result on the employment of persons covered by the firm's pension plan is negligible.

(c). Increase the SS Retirement Ages by One Year. Current plans are to increase the Social Security retirement age from 65 to 67 by 2027 . To Judge

${ }^{21}$ This reduction is intended to be actuarially fair. 
(57)

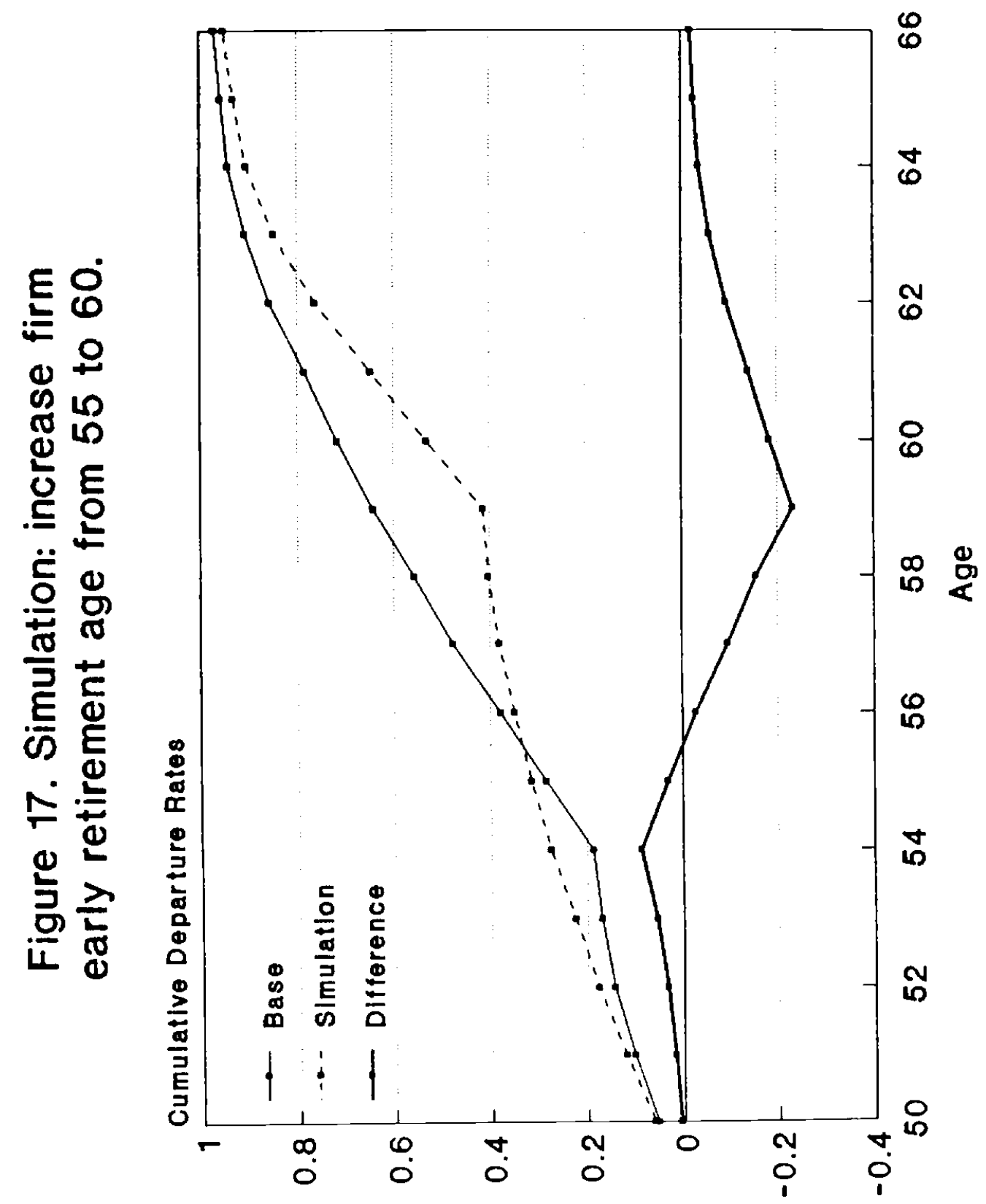




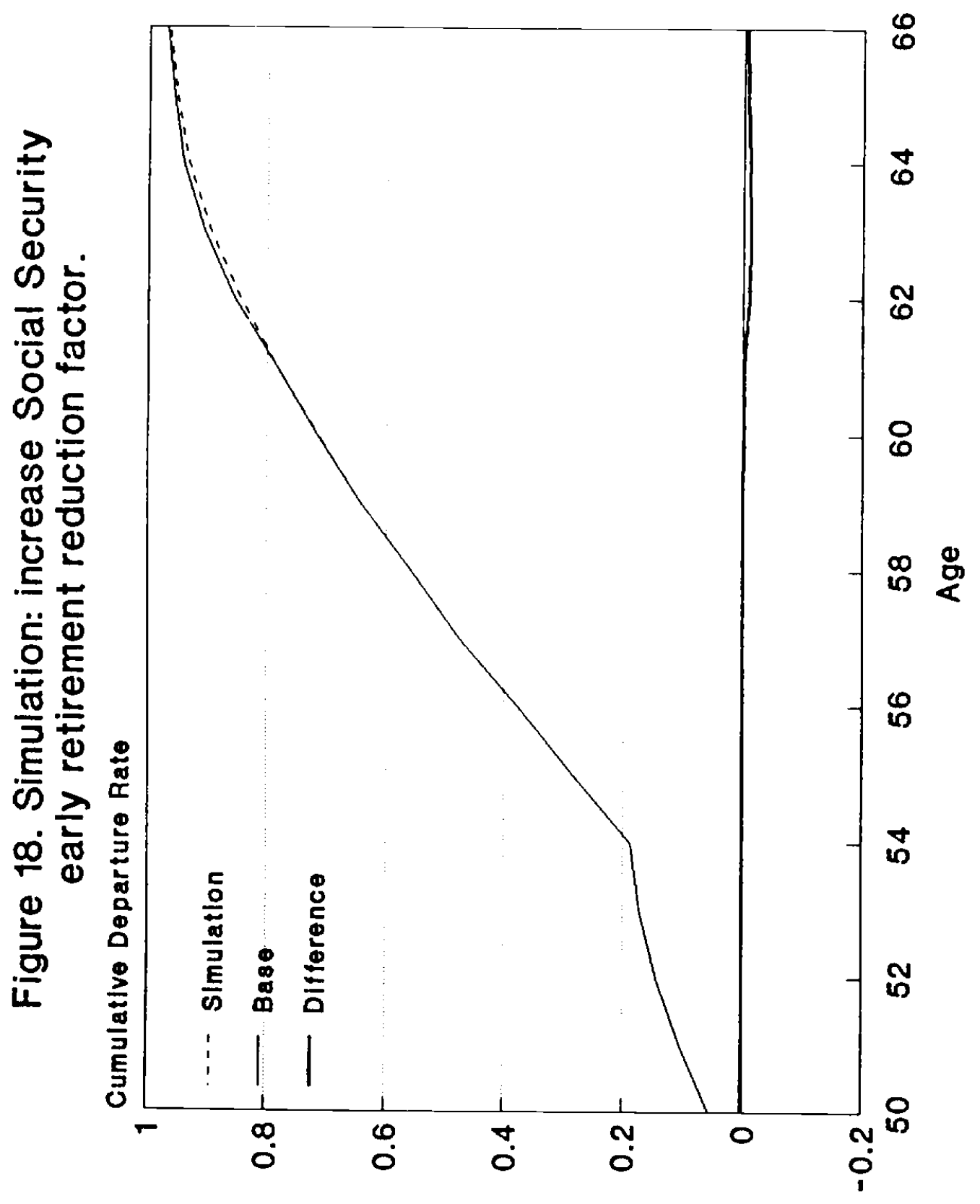


the effect of such a change on workers with pension plans 11 ke the one in this firm. Stock and Wise [1988] simulated the ffect of Increasing the normal retirement age from 65 to 66 and the early retirement age from 62 to 63 . The results are in figure 19. Again, the effect on the retirement rates of persons in this firm is small. Th1s is true evon though the offect on the annual retirement rates of 62 and 65 year, olds 1 s substantial. The retirement rate of 62 -year-olds $1 \mathrm{~s}$ reduced from 33.9 to 25.2 percent. The rate at 65 is reduced from 28.6 to 25.1 . But only a few workers remain in the firm to be affected by these changes.

(d). The Effect of a Spectal Window Plan. During 1982, the firm had a special retirement incentive program (a "window" plan) that provided up to one year's salary, In addition to regular retirement benefits, for employees who retired in that year. The effects of this plan on the retirement behavior of non-managerial office workers were simulated by Lumsdaine, Stock, and Wise [1989] and are shown in figure 20. For comparison, the figure shows retirement rates in 1981 and then actual and simulated retirement rates in 1982. (Evidence on the effects of this plan is also shown in table 2 above.) It is clear that the plan had a very large effect. Annual departure rates were more than doubled for many age groups. In addition, the figure indicates the extent to which the option value model was able to predict the effect of this exogenous change in "retirement benefits."

IV. Summary.

The labor force participation of older Americans has decilned dramatically since the inception of Social Security and the tax inducement to develop f1rm pension plans. Between 1937 and 1980 the participation rate of men over 60 fell from about 62 to about 32 percent, and it continues to 
(60)

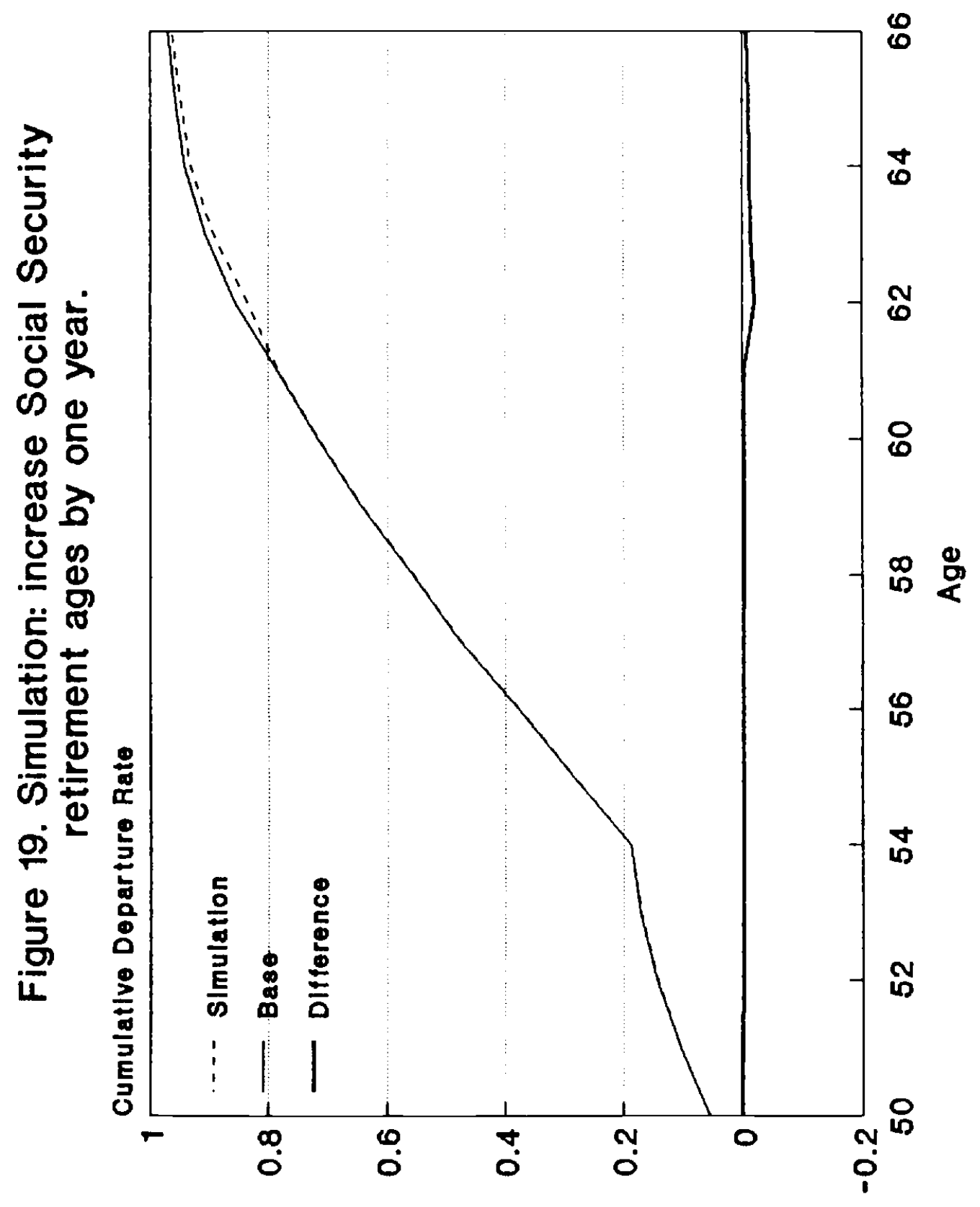


(61)

Figure 20. Actual retirement rates in 1981 and 1982 vs. simulated 1982 retirement rates under the window plan, based on 1980 model 3 parameter estimates.
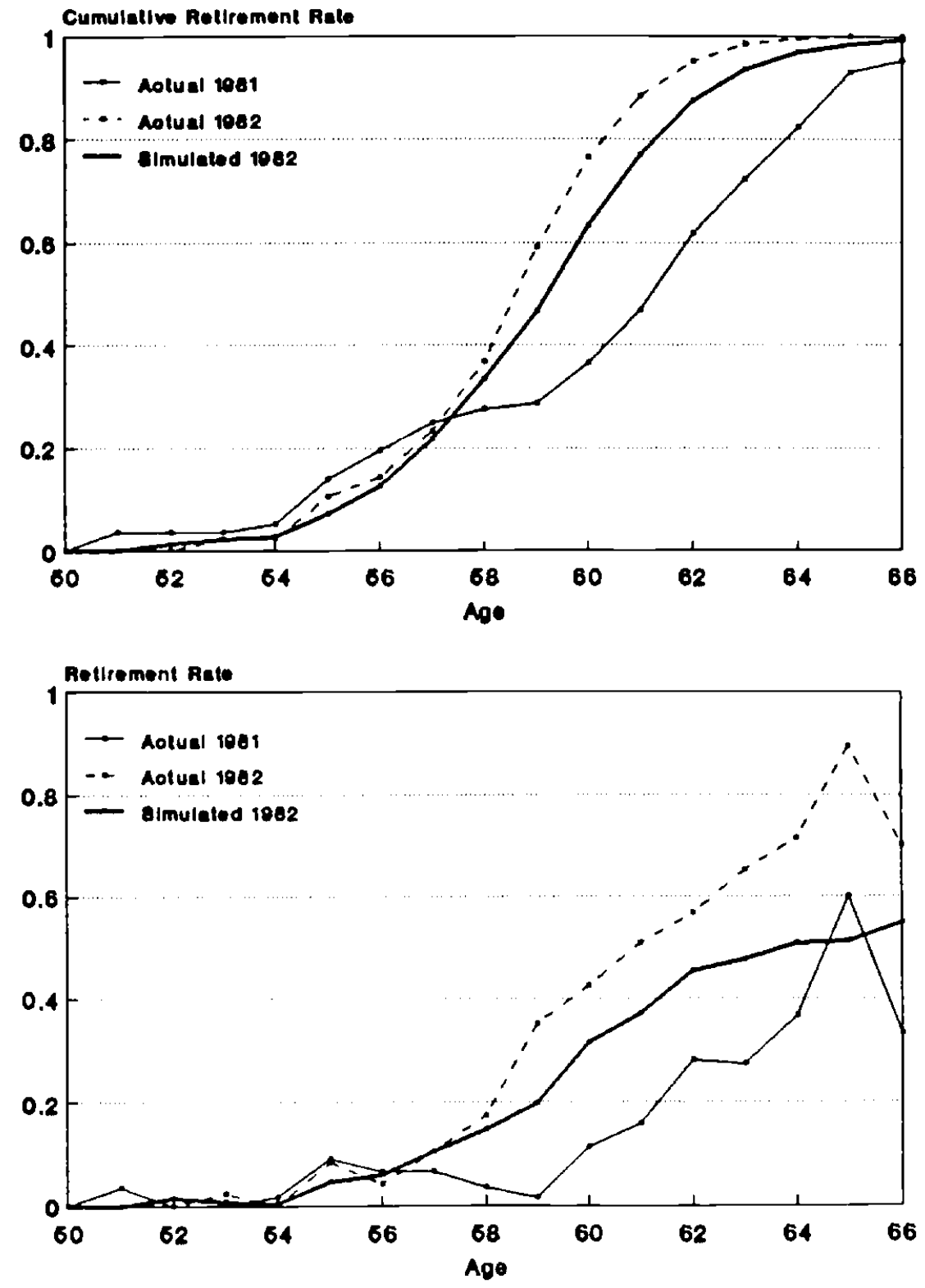
decline. Even the rate for older women has declined since 1970. It seems evident that the decline has resulted from the retirement income made possible by these programs. The vast majority of the income of most retirees now comes from pension and Social Security benefits. Most retirement age families have almost no personal saving other than housing wealth. Yet the average income of older families has increased dramatically in the past three decades, possibly three fold between 1963 and 1978 alone. With reference to figure 1 , the retirement benefits curve has been ralsed. From the point of view of the individual, the wealth associated with SS and firm pension benefits encourages earliel retirenent.

But it is not only the amount of the SS and pension wealth that matters. How it accumulates is also important. For example, if no benefits were avallable until age 70 , few employees would retire at age 55 . If retirement wealth accumulates rapidly between 55 and 60 and then starts to decline, employees have an incentive to retire soon after age 60 . In effect, the reduction in the accumulation of retirement walth is like a reduction in the wage; both reduce the incentive for labor force participation. In fact, the formulas determining firm pension benefits in particular tend to encourage continued employment with the firm unt1l some age - often between 55 and 60 - and provide an incentive to leave the firm thereafter - the annual addition to retirement wealth is reduced or even negative. The addition to retirement wealth after age 65 is almost always negative. The amount of the retirement benefit is not increased enough for a person who retires one year later to offset the fact that the benefit is recelved for one year less.

Thus even though individuals are living longer and even though a larger fraction of the population is old, workers are leaving the labor force at 
younger and younger ages. The retired portion of the population is increasing, the employed portion is declining. Whether by intent or by happenstance, firm pension plan and Social Security provisions continue to encourage this trend. 


\section{References}

Allen, Steven G., Robert L. Clark, and Ann A. McDermed. 1986. "Job Mobility, 0lder Workers and the Role of Pensions." Mimeo.

Allen, Steven G., Robert L. Clark, and Ann A. McDermed. 1987. "Why Do Pensions Reduce Mobility?" Mimeo.

Allen, Steven G., Robert L. Clark, and Ann A. McDermed. 1988. "Pensions and Lifetime Jobs: The New Industrial Feudalism Revisited." Mimeo.

Berkovec, James and Steven Stern. 1988. "Job Exit Behavior of Older Men." Mimeo.

Blinder, Alan, Roger Gordon, and Donald Wise. 1980. "Reconsidering the Work Diaincentive Effects of Social Security." National Tax Journal, Vol. 33, December, pp. $431-442$.

Bulow, J. 1981. "Early Retirement Pension Benefits." NBER Working Paper No. 654 .

Burkhauser, Richard V. 1979. "The Pension Acceptance Decision of Older Workers." Journal of Human Resources XIV(1), pp. 63-75.

Burkhauser, Richard V. 1980. "The Early Acceptance of Social Security: An Asset Maximization Approach." Industrial and Labor Relations Review, Vol. 33, pp. 484-92.

Burkhauser, Richard V. and Joseph Quinn. 1983. "Inferring Retirement Behavior: Key Issues for Social Security." Journal of Pollcy Analysis and Management, Vol. 3, No. 1, Fall, pp. 1-13.

Burtless, Gary. 1986. "Social Security, Unanticipated Benefit Increases, and the Timing of Retirement." Review of Economic Studies 53, pp. 781-805. Burtless, Gary and Jerry A. Hausman. 1978. "Double Dipping': The Combined Effects of Social Security and Civil Service Pensions on Employee Retirement." Journal of Polftical Economy 18, pp. 139.160. 
Burtless, Gary and Robert A. Moffitt. 1984. "The Effects of Soclal Security on the Labor Supply of the Aged," In H. Aaron and G. Burtless (eds.) Retirement and Economic Behavior. Washington, DC: Brookings Institute, pp. $135-174$.

Clerk, Robert L. and Ann A. McDermed. 1984. "Life Cycle Patterns of Earnings, Pension Wealth, and Total Compensation." Mimeo.

Clark, Robert L. and Ann A. McDormod. 1987. "Pension Wealth and Job Changes: The Effects of Vesting Portability and Lump-Sum Distributions." Working Paper. Raleigh: North Carolina University.

Ellwood, David I. 1985. "Penslons and the Labor Market: A Starting Point (The Mouse Can Roar)," in D. Wise (od.) Rensions. Laber. and Individual Cholce. Chicago: University of Chicago Press, Pp. 19.49.

Fields, Gary S. and Olivia Mitchell. 1982. "The Effects of Pensions and Earnings on Retirement: A Review Essay, " In R. Ehronberg (od.) Research in Labor Econemles, Vol. S, Pp. 115-156. Greenwich, CT: JAL Press.

Flelds, Gary S. and Olivia Mitchell. 1984. Retirement. Pensions and Soctal Security. Cambridge, MA: MIT Press.

Frant, Howard L. and Herman B. Leonard. 1987. "Prom1se Them Anything: The Incentive Structures of Local Public Pension Plans," In D. Wise (ed.) Public Secter Parrolls. Chicago: University of Chicago Press, pp. 215 . 242.

Gustman, Alan and Thomas Stelnmeler. 1986. "A Structural Retirement Model." Econometrica Vol. 54, pp. 555-584.

Gustman, Alan and Thomas Steinmeler. 1987. "Job Mobllity, Older Workers and the Role of Pensions." Mimeo. 
Hausman, Jerry A. and David A. Wise. 1980. "Discontinuous Budget Constraints and Estimation: The Demand for Housing." Review of Economic Studies XLVII, pp. 75-96.

Hausman, Jerry A. and David A. Wise. 1985. "Social Security, Health Status, and Retirement," in D. Wise (ed.), Penstens. Labor and Individual Cholce. Chicago: Untversity of Chicago Press, pp. 159-191.

Hogarth, Jeanne M. 1988. "Accepting an Early Retirement Bonus: An Emplrical Study." Journal of Human Resources XXIII(1), pp. 21-33.

Hurd, Michael and Michael Boskin. 1981. "The Effect of Soclal Security on Retirement in the Early 1970s." Quarterly Journal of Economics, November, pp. $767-790$.

Hurd, Michael D. and John B. Shoven. 1982. "Real Income and Wealth of the Elderly." Amertcan Economic Review 72, pp. 314-318.

Kotlikoff, Laurence J, and Danlel E. Smith. 1983. Renstens in the American Economy. Chicago: University of Chicago Press.

Kotlikoff, Laurence J, and David A. Wise. 1985. "Labor Compensation and the Structure of Private Pension Plans: Evidence for Contractual versus Spot Labor Markets," In D. Wise (ed.), Penstens Labor and Individual Cholce. Chlcago: University of Chlcago Press, pF. 55-85.

Kotlikoff, Laurence J, and David A. Wise. 1987. "The Incentive Effects of Private Pension Plans," In Z. Bodle, J, Shoven, and D. Wise (eds.) Issues In Penston Ecenomics. Chicago: University of Chicago Press, pp. 283-336. Kotlikoff, Laurence J. and David A. Wise. 1989. "Employee Retirement Behavior and a Firm's Pension Plan," In D. Wise (ed.), The Economics of Aging. Chlcago: University of Chlcago Press, pp. $279-330$. Lazear, Edward P. 1979. "Why Is there Mandatory Retirement?" Journal of Polftical Economy $87: 1261-64$. 
Lazear, Edward P. 1983. "Pensions as Severance Pay," In Z. Bodie and J. Shoven (ed.) Einanclal Aspects of the United States Pension System.

Chicago: University of Chicago Press, Pp. 57-89.

Lazear, Edward P. and Robert L. Moore. 1988. "Pensions and Turnover," In Z. Bodle, J. Shoven, and D. Wise (eds.), Pensions in the U.S. Economy. Chicago: University of Chicago Press, pp. 163-188. Lumsdaine, Robin L., James H. Stock, and David A. Wise. 1989. "Windows and Retirement." Forthcoming in Annales d'Economie et de Statistigues.

Nalebuff, Barry and Richard J. Zeckhauser. 1985. "Pensions and the Retirement Decision," In D. Wise (ed.) Pensions Labor and Individual Cholce. Chicago: University of Chicago Press, Pp. 283-316. Phillips, Douglas and Dav1d A. Wise. 1987. "Military versus Civilian Pay: A Descriptive Discussion," In D. Wise (ed.) Public Sector Payrolls. Chicago: University of Chlcago Press, pp. 19-46.

Poterba, James M. and Lawrence H. Summers. 1987. "Public Policy Implications of Declining Old-Age Mortality," In G. Burtless (od.) Work. Health, and Income Among the Elderly. Washington, DC: Brookings Institute Press, Pp. 19.51 .

Ransom, Roger L. and Richard Sutch. 1988. "The Decline of Retirement and the RIse of Efflclency Wages: U.S. Retirement Patterns, 1870-1940, " in R. Ricardo-Campbell and E. Lazear (eds.) Issues in Contemporary Retirement. Stanford, CA: Hoover Institution, pp. 3-37. Rust, John. 1988. "A Dynam1c Programming Model of Retirement Behavior: Empirical Results." Mimeo.

Rust, John. 1989. "A Dynamic Programing Model of Retirement Behavior," in D. Wise (ed.), The Economics of Aging. Chicago: University of Chicago Press, pp. $359-398$. 
Sandefur, Gary D. and Nancy Brandon Tuma. 1987. "Social and Economic Trends Among the Aged in the United States, 1940-1985." Mimeo.

Stock, James H. and David A. Wise. 1988. "The Pension Inducement to Retire: An Option Value Analysis." NBER Working Paper No. 2660.

Stock, James H. and David A. Wise. 1989. "Pensions, The Option Value of Work, and Retirement." NBER Working Paper No. 2686. Forthcoming in Econometrica.

Summers, Lawrence and Chris Carroll. 1987. "Why is U.S. National Saving So Low?" Brooktings Papers on Economic Act1vity 2, pp. 607-642.

Tuma, Nancy Brandon, and Gary D. Sandefur. 1988. "Trends in the Labor Force Activity of the Aged in the United States, 1940-1980," In R. RicardoCampboll and E. Lazear (eds.) Issues in Contemporary Retirement. Stanford, CA: Hoover Institution, pp. $38-83$.

U.S. Bureau of the Census. "Pensions, Worker Coverage, and Retirement Income, 1984." Current Population Reports P-70, No. 12.

U.S. Bureau of the Census. "Poverty in the U.S., 1986." Current Population Reports P-60, No. 160, Table 28 .

U.S. Bureau of the Census. 1984. "Projections of the Population of the U.S., by Age, Sex, and Race, 1983-2080." Current Pepulation Reports P-25, No. 952. Table 6 .

Vent1, Steven F. and Devid A. Wise. 1984. "Moving and Housing Expenditure: Transaction Costs and Disequilibrium." Journal of Public Economics 23 , pp. 207-243.

Vent1, Steven F. and David A. Wise. 1987. "Have IRAs Increased U.S. Saving?: Evidence from Consuner Expenditures Surveys." NBER Working Paper No. 2217. Forthcoming in The Quarterly Journal of Economics. 
Venti, Steven F, and David A. Wise, 1989. "Aging and the Income Value of Housing Wealth." Mimeo.

W1se, Devid A. (od.). 1985. Rensions, Labor. and Individual Cholce.

Chicago: Univeraity of Chicago Press. 
</ref_section> 